\title{
Asymmetric risks of momentum strategies
}

\section{Victoria Dobrynskaya ${ }^{1}$}

First version: November 2013

This version: March 2014

\begin{abstract}
I provide a novel risk-based explanation for the profitability of global momentum strategies. I show that the performance of past winners and losers is asymmetric in states of the global market upturns and downturns. Winners have higher downside market betas and lower upside market betas than losers, and hence their risks are more asymmetric. The winner-minus-loser (WML) momentum portfolios are exposed to the downside market risk, but serve as a hedge against the upside market risk. The high returns of the WML portfolios compensate investors for their high risk asymmetry. After controlling for this risk asymmetry, the momentum portfolios do not yield significant abnormal returns, and the momentum factor becomes insignificant in the cross-section. The two-beta CAPM with downside risk explains the cross-section of returns to global momentum portfolios well.
\end{abstract}

JEL classification: G12, G15

Keywords: momentum, reversal, downside risk, downside beta, upside beta, risk asymmetry

\footnotetext{
1 London School of Economics, National Research University Higher School of Economics, and Center for Empirical Finance at Russian Presidential Academy of National Economy and Public Administration. E-mail: v.v.dobrynskaya@1se.ac.uk, tel. +79166864264.

I am very grateful to Christopher Polk, Christian Julliard, Dong Lou, Andrea Vedolin, Philippe Mueller and seminar participants at London School of Economics and Gaidar Institute for Economic Policy for their comments and suggestions.
} 


\section{INTRODUCTION}

Since Jegadeesh and Titman (1993), the momentum anomaly has received a lot of attention. Buying past winners and selling past losers generates abnormal returns in the short run, which cannot be explained by conventional risk measures (e.g. the standard deviation and the market beta) and provide evidence for market inefficiency. Momentum strategies proved to be profitable around the world, at the level of national equity indices (e.g. Asness, Liew, and Stevens, 1997; Richards, 1997; Cenedese et al., 2013) and at the individual stock level (Rouwenhorst, 1998, 1999), among currencies (Okunev and White, 2003; Menkhoff et al., 2012), commodities, bonds and other assets (Gorton et al., 2008; Asness, Moskowitz, and Pedersen, 2013).

In this paper, I provide a novel risk-based explanation for the profitability of global momentum strategies. I show that the performance of past winners and past losers is asymmetric in states of the global market upturns and downturns. Winners have higher downside market betas and lower upside market betas than losers, and hence their upside and downside risks are asymmetric. Greater relative downside risk and lower relative upside risk of past winners are compensated by higher returns. Indeed, such asymmetry in upside and downside market risks explains the returns to the crosssection of global momentum portfolios well.

The importance of separating the overall market risk into the upside and downside risks for asset pricing was recognized in early papers (e.g. Roy, 1952; Markowitz, 1959; Bawa and Lindenberg, 1977) and was articulated in Ang and Chen (2002) and Ang et al. (2006) for the US stock market. More recently, Lettau et al. (2014) and Dobrynskaya (2014) provide further convincing evidence that the models with downside risk (e.g. two-beta CAPM) have greater explanatory power in the stock, currency, commodity and bond markets. They show that the downside risk is a unifying explanation for returns in different asset markets.

Although numerous explanations for the momentum anomaly have been put forward, their upside and downside market risks has not been studied thoroughly. DeBondt and Thaler (1987) find 
that past winner stocks have greater downside betas than upside betas. Ang et al. (2001) find that the US momentum portfolio has positive and significant loading on a factor that reflects downside risk, and that the downside risk factor explains some of the cross-sectional variation in returns to momentum portfolios. Lettau et al. (2014) consider six US Fama-French size-momentum portfolios and find some evidence that the returns are "broadly positively associated with the downside beta".

Building on these studies, I show that the downside risk alone does not fully explain the returns to the cross-section of momentum portfolios because the upside risk plays a significant role too. In fact, it is the difference in the upside and downside betas (beta asymmetry) which varies across momentum portfolios. For any set of momentum portfolios considered, the asymmetry in betas is monotonically increasing from losers to winners and it is statistically significant. As a result, the winner-minus-loser momentum portfolios are exposed to the downside risk, but hedge against the upside risk. In other words, the momentum portfolios perform badly in states of global market upturns. This finding goes in line with Daniel and Moskowitz (2013) who show that momentum portfolios crash when the market rebounds after a market decline, and when the market return is high.

In the cross-section tests, I show that the relative downside beta, which captures the extra downside risk and, hence, the downside-upside risk asymmetry, explains the returns to the momentum portfolios well, whereas the traditional beta has no explanatory power. The relative downside beta premium is approximately 3-4 percent per month, highly statistically significant and similar in magnitude to the estimates obtained for the stock and currency markets (Lettau et al., 2014; Dobrynskaya, 2014).

My findings are similar no matter which set of momentum portfolios I consider. I study the US, global and regional momentum portfolios of individual stocks, global momentum portfolios of country indices, currency momentum portfolios and US short-term and long-term equity reversal portfolios. I show that momentum is a global phenomenon indeed, and its upside-downside risk 
structure is similar around the world and in different asset markets. Hence, the upside-downside risk asymmetry can be considered a unifying explanation of returns to momentum portfolios in various markets. The results are robust to different estimation methodologies (Fama-MacBeth (1973) and Hansen's (1982) GMM) and different periods of study.

The rest of the paper is organized as follows. In section 2, I describe the theoretical asset pricing models with downside risk to motivate my risk measures. Section 3 is devoted to the data description and portfolio formation. In section 4 , I present the portfolio statistics and the results of the crosssection tests for different sets of momentum and reversal portfolios. Section 5 concludes the paper.

\section{CAPM WITH UPSIDE AND DOWNSIDE RISKS}

The importance of upside and downside risks was recognized as early as the first theoretical assetpricing models were developed. Roy (1952) suggests that economic agents care particularly about the downside risk. Markowitz (1959) proposes using semi-variance as a proper measure of risk. Bawa and Lindenberg (1977) provide an extended version of the CAPM where the market beta is separated into the upside beta and the downside beta. Longin and Solnik (2001) consider upside and downside correlations, and Ang and Chen (2001) propose a measure of correlation asymmetry and show that the asymmetric correlation is priced in the US equity market.

Ang et al. (2006) show how upside and downside risks may be priced cross-sectionally in an equilibrium setting. In a theoretical model with disappointment aversion, they show numerically that the traditional CAPM alpha is increasing in the relative downside beta, decreasing in the relative upside beta and, hence, increasing in the downside-upside beta asymmetry. Assets should have higher expected returns if they have higher relative downside betas because such assets perform poorly in bad states of the world when the marginal utility of wealth is high and asset returns are particularly important. Assets with high relative upside betas, on the contrary, do not require a high risk premium, because the marginal utility of wealth is low in such states. 
Ang et al. (2006) test the validity of the two-beta CAPM in the US stock market. They find that, indeed, the upside and downside risks are priced differently, and that the two-beta CAPM has a much higher explanatory power than the traditional CAPM. Even after controlling for other risk factors (size, book-to-market, momentum, liquidity and volatility), the estimates of the downside risk premium are statistically significant.

More recently, asset pricing models with downside market risk proved to be as successful in explaining returns in the currency, commodity and bond markets (Lettau et al, 2014; Dobrynskaya, 2014), as in the equity market. The downside risk is shown to be priced similarly in different asset markets and different geographical markets.

\section{DATA AND PORTFOLIO FORMATION}

I consider a variety of momentum and reversal portfolios around the globe to show that the upsidedownside risk asymmetry is a universal phenomenon.

Firstly, I consider 10 US equal-weighted and value-weighted momentum portfolios, which are formed by sorting NYSE, AMEX and NASDAQ stocks in month $t$ by their total returns in months t12 to $\mathrm{t}-2$. The month prior to the sort date is excluded because of the short-term reversal. Portfolio 1 (low) is the past-loser portfolio, and portfolio 10 (high) is the past winner portfolio. I also construct the winner-minus-loser (WML) portfolios which have a long position in portfolio 10 and a short position in portfolio 1 . The longest time series of data is available for these portfolios: from January 1927 until July 2013. The data is taken from the Fama-French data library.

Secondly, I consider global and regional momentum portfolios of individual stocks. These portfolios are formed by monthly sorts of stocks in the corresponding region by their previous-year $(\mathrm{t}-12$ to $\mathrm{t}-2)$ performance. The data on these portfolios is also obtained from the Fama-French data library and covers the period from November 1990 until August 2013. I collect the raw data on 25 equal-weighted Global, European, Asian-Pacific, Japanese and North-American size-momentum 
portfolios and construct 5 momentum portfolios and 5-1 WML portfolio for each region. The Global portfolios consist of stocks from 23 countries: Australia, Austria, Belgium, Canada, Denmark, Finland, France, Germany, Greece, Hong Kong, Ireland, Italy, Japan, the Netherlands, New Zealand, Norway, Portugal, Singapore, Spain, Switzerland, Sweden, the UK, and the USA; the European portfolios consist of stocks from 16 countries; the Asian-Pacific portfolios consist of stocks from 4 countries; and the North-American portfolios consist of stocks from Canada and the USA.

The third set of momentum portfolios is formed by double sorts of individual stocks by their previous year performance and the market capitalization. I consider global 25 size-momentum portfolios form the Fama-French data library.

The fourth set of global momentum portfolios is formed by sorting country indices in month $\mathrm{t}$ by their total returns in US dollars in months $\mathrm{t}-12$ to $\mathrm{t}-2$. The portfolios are rebalanced every month. Following Richards (1997) and Cenedese et al. (2013), I use MSCI country indices as the base assets. These indices often represent a benchmark for country index ETFs, and hence they are traded assets which can be used to form such momentum portfolios in practice. There are 40 countries in the sample: Australia, Austria, Belgium, Brazil, Canada, Czech Republic, Denmark, Egypt, Finland, France, Germany, Greece, Hong Kong, Hungary, India, Indonesia, Ireland, Israel, Italy, Japan, South Korea, Malaysia, Mexico, the Netherlands, New Zealand, Norway, Philippines, Poland, Portugal, Russia, Singapore, South Africa, Spain, Sweden, Switzerland, Taiwan, Thailand, Turkey, the UK, and the USA. The sample period is from January 1983 until August 2013, the first sort is done in December 1983 and the first return is measured in January 1984. For 20 countries, the indices are available for the whole period, 12 indices start in December 1987, 4 indices start in December 1992 and 4 indices start in December 1994. I form 6 equally-weighted portfolios of indices, where portfolio 1 represents past loser countries and portfolio 6 represents past winner countries. Once new indices appear, they enter the portfolios a year later, and the portfolios become more diversified. I also form the 6-1 WML portfolio which represents a global momentum strategy. 
The fifth set consists of 5 currency momentum portfolios which are formed by sorting currencies in month $\mathrm{t}$ by their exchange rate appreciation relative to the US dollar during the period $\mathrm{t}-12$ to $\mathrm{t}-2$ and held for 1 month. The sample consists of 45 currencies, but the actual number of currencies varies from 10 (November 1984) to 41 (December 1998) due to data limitations and creation of the Euro zone. The exchange rate data cover the period from October 1983 until August 2013, the first sort is done in October 1984 and the first portfolio returns are measured in November 1984. The endof-month exchange rate data are collected from various data sources via Datastream.

I also consider short-term and long-term reversal portfolios of US stocks for the periods January 1927 - July 2013 and January 1931 - July 2013, respectively. The short-term reversal portfolios are sorted by the performance in the previous month, whereas the long-term reversal portfolios are sorted by the performance in the previous five-year period. All portfolios are rebalanced monthly. The data is taken from the Fama-French data library.

I use the following risk factors in the analysis: the market factor (the US market index for the US portfolios and the developed countries World MSCI index for the global and regional portfolios), the market volatility factor (the squared market factor), the momentum factor (the Fama-French US momentum factor before November 1990, the Fama-French global momentum factor afterwards, which is formed by sorting individual stocks in 23 countries by their trailing previous-year performance), and the global size factor (the Fama-French global SMB factor).

\section{RESULTS}

\subsection{US MOMENTUM PORTFOLIOS}

I start the analysis of US momentum portfolios because the longest time series of data is available for these portfolios. Table 1 reports the return and risk characteristics of 10 value-weighted and 10 equal-weighted momentum portfolios, as well as the WML zero-cost portfolios. 
The momentum effect is strong in the US; the zero-cost value-weighted (equal-weighted) momentum strategy generated an average return of 14.27 (9.80) percent per annum during 1927 2013.Past-winner portfolios generally have lower return standard deviation, skewness, kurtosis and market betathan past loser portfolios, but higher returns. Therefore, the WML portfoliosgenerate high and virtually risk-free returns, if these measures of risk are considered. This represents the wellknown momentum anomaly.

Keeping the Ang et al. (2006) two-beta CAPM in mind, I estimate the upside and downside market betas of the momentum portfolios in the following time-series regression:

$$
r_{i t}=\alpha_{i}+\beta_{i}^{-} * r_{M t}+\gamma_{i} * r_{M t} * D_{t}
$$

where $D_{t}=\left\{\begin{array}{l}0, r_{M t} \leq 0 \\ 1, r_{M t}>0\end{array}, r_{i t}\right.$ is the return on portfolio $i, r_{M t}$ is the US market return, $\beta_{i}^{-}$is the estimate of the downside beta ${ }^{2}, \gamma_{i}$ is the estimate of the upside-downside beta asymmetry, and hence the upside beta $\beta_{i}^{+}=\beta_{i}^{-}+\gamma_{i}$. Then, the relative downside beta is $\left(\beta_{i}^{-}-\beta_{i}\right)$, and the relative upside beta is $\left(\beta_{i}^{+}-\beta_{i}\right)$, where $\beta_{i}$ is the traditional beta, estimated in the regression of portfolio return on the market return. This approach to estimate the upside and downside betas jointly is superior to the one, used in Lettau et al. (2014), because no information regarding the upside is $\operatorname{lost}^{3}$. The relative downside beta measures additional market risk on the downside, after controlling for the overall market risk (the traditional market beta). A portfolio may have lower market beta, but greater exposure to the downside risk, and hence may require higher returns, because investors care more about performance in downstates. This can only be seen after separating the overall market risk and the downside market risk.

\footnotetext{
${ }^{2}$ As defined here, the downside beta is conditional on the negative market return. Another way to define downside beta is to condition on the episodes when the market return is below its mean. This alternative specification produces similar results and it is not reported.

${ }^{3}$ Lettau et al. (2014) just pick the downside episodes and estimate the downside beta in that sub-sample.
} 
Table 1 reports the relative downside betas, the relative upside betas and the beta asymmetry $\left(\beta_{i}^{-}-\beta_{i}^{+}=-\gamma_{i}\right)$ of the US momentum portfolios. We observe a striking increasing pattern for the relative downside betas and decreasing pattern for the relative upside betas along the portfolio rank. Past winner portfolios have higher downside risk and lower upside risk than past loser portfolios. Therefore, the WML portfolios are exposed to the downside risk, but hedge against the upside risk. Since the downside risk is more important for an investor, the WML portfolios require risk premiums.

Because both the relative downside betas and the relative upside betas are different for past winners and past losers, there is an even stronger positive relationship between the beta asymmetry and portfolio rank. Past losers have higher upside betas than downside betas, whereas past winners have higher downside betas than upside betas. The beta asymmetry ranges from -0.71 to 0.99 and it is statistically significant for several top and bottom portfolios, as well as the WML portfolios. The results are similar in cases of value-weighted and equal-weighted portfolios.

Figure 1 illustrates the relationships between the relative upside betas, relative downside betas, beta asymmetry and portfolio rank (for the value-weighted portfolios). We observe clear monotonic relationships.

The differences in the upside and downside risks of momentum portfolios can explain the differences in their returns. Figure 2 plots the predicted versus realized returns of US momentum portfolios, where the predictions are made by the traditional CAPM (left-hand-side) and the two-beta CAPM (right-hand side). Indeed, the two-beta CAPM has very high explanatory power $\left(\mathrm{R}^{2}\right.$ of 0.93 and 0.94), whereas the traditional CAPM performs worse $\left(\mathrm{R}^{2}\right.$ of 0.46 and 0.66$)$, and the beta premium is even negative.

I use the following specification of the two-beta CAPM for the cross-section regressions:

$$
r_{i}-r_{f}=\beta_{i} \lambda+\left(\beta_{i}^{-}-\beta_{i}\right) \lambda^{-}+\mu,
$$


where $\lambda$ is the traditional beta premium, $\lambda^{-}$is the extra downside beta premium, and $\mu$ is the common pricing error, which can be restricted to zero ${ }^{4}$. This specification nests the traditional CAPM if the extra downside risk is not priced or if the downside beta is equal to the traditional beta (and, hence, to the upside beta). This specification of the two-beta CAPM (called downside-risk CAPM) was estimated in Lettau et al. (2014) for different asset classes, and it is alternative to the specification of Ang et al. (2006):

$$
r_{i}-r_{f}=\beta_{i}^{+} \lambda^{+}+\beta_{i}^{-} \lambda^{-}+\mu
$$

where $\lambda^{+}$is the upside beta premium and $\lambda^{-}$is the downside beta premium. Since the traditional beta is a weighted average of the upside beta and the downside beta, we need to have any two betas of the three to fully specify the model. If the relative downside beta premium is positive, it means that the relative upside beta premium is negative. Specification (2) is more convenient because we can easily compare it with the traditional CAPM specification and see the contribution of the relative downside risk.

Table 2 reports the estimates of risk premiums in the cross-section tests of the traditional CAPM and the downside-risk CAPM (DR-CAPM) with and without the constant. I employ two alternative methodologies to estimate risk premiums: the Fama-MacBeth (1973) and Hansen's (1982) two-step GMM. In the latter, the factor betas and risk premiums are estimated jointly, and the standard errors are corrected to account for the generated regressor problem. I use the identity weighting matrix in the first step, and then re-optimize using the efficient weighting matrix. The moment conditions are specified as in Cochrane (2005):

$$
\left\{\begin{array}{l}
E\left(r_{j t}-\alpha_{j}-b_{j} f_{t}\right)=0 \\
E\left(r_{j t}-\alpha_{j}-b_{j} f_{t}\right) \otimes f_{t}=0 \\
E\left(r_{j t}-b_{j} \lambda-\mu\right)=0
\end{array}\right.
$$

\footnotetext{
${ }^{4}$ It is common in the recent literature to restrict the pricing error to zero (e.g. Burnside et al., 2011; Lustig et al., 2011; Cenedese et al., 2013).
} 
where $f_{t}$ is either a risk factor or a vector of factors, $r_{j t}$ is the excess return on portfolio $j, b_{j}$ is a factor beta, and $\lambda$ is a factor risk premium. The first two moments estimate factor betas, and the third moment estimates factor risk premiums.

The traditional CAPM has negative $\mathrm{R}^{2}$ in case of no constant, and negative beta premiums, significant intercepts and low $\mathrm{R}^{2}$ in case with a constant. It is also rejected by the test for the overidentifying restrictions (J-statistics). Therefore, the traditional CAPM cannot explain the returns to the momentum portfolios. The downside-risk CAPM, on the contrary, performs very well in terms of both $\mathrm{R}^{2}$ and J-statistics. The relative downside beta premium is about 2 percent per month and it is highly significant irrespective of the estimation methodology 5 . The same magnitude of the downside risk premium was also obtained in Dobrynskaya (2014) for equity and carry trade portfolios. In case with a constant, the traditional beta premium and the constant are insignificant, so that the full explanatory power of the model comes from the downside risk component. The high momentum return is a compensation for its high relative downside risk and high downside-upside risk asymmetry.

My results differ from Lettau et al.'s (2014) results who do not find such a strong support for the downside-risk CAPM in the cross-section of six US size-momentum portfolios, although they write that the returns are "broadly positively associated with the downside beta". The reason is that they look at the downside betas instead of relative downside betas which measure downside-upside beta asymmetry. It turns out that the downside betas of these portfolios are similar and, hence, they cannot explain the differences in these portfolio returns. But the relative downside betas, relative upside betas and the downside-upside-beta asymmetry vary across the portfolios significantly and are well aligned with the portfolio returns. Neglecting the upside component leads to misinterpretation of

\footnotetext{
${ }^{5}$ In an alternative specification of the two-beta CAPM with relative upside betas instead of the relative downside betas, the relative upside beta premium is negative and the explanatory power of the model is exactly the same by construction. These results are not reported because they are redundant.
} 
the results. I confirm the validity of the downside-risk CAPM for the cross-section of 25 global sizemomentum portfolios in section 4.3.

\subsection{GLOBAL AND REGIONAL MOMENTUM PORTFOLIOS OF STOCKS}

In this section, I consider global and regional momentum portfolios of individual stocks and show that the downside-upside risk asymmetry of momentum returns is a global phenomenon. Table 3 reports the returns and risks of 5 global, 5 European, 5 Asian-Pacific and 5 North-American momentum portfolios and the corresponding 5-1 WML portfolios. The momentum strategies are profitable in all regions with the highest momentum return in Europe (17.58 percent pa) and the lowest momentum return in the Asian-Pacific region (6.55 percent pa $)^{6}$.

In all regions, the high returns to the WML portfolios cannot be explained by the market factor because their global market betas are negative in all cases, as in Fama and French (2012). While the market betas are somewhat decreasing with the portfolio rank, the relative downside betas are monotonically increasing and the relative upside betas are monotonically decreasing. The past winner portfolios have greater exposure to the downside risk and lower exposure to the upside risk than the past loser portfolios. Consequently, the winner portfolios exhibit a greater degree of the downside-upside risk asymmetry $\left(\beta^{-}-\beta^{+}\right)$. This asymmetry is statistically significant for the winner and WML portfolios in all regions. In general, the global and regional momentum portfolios have similar risk structure as the US momentum portfolios despite the different base assets and different sample periods.

As in the US case, the two-beta CAPM has a high explanatory power in the cross-section of momentum portfolios in all regions (figure 3). The predicted returns are very close to the realized returns with $\mathrm{R}^{2}$ of $77-96$ percent.

\footnotetext{
${ }^{6}$ The exception is Japan where the WML portfolio is unprofitable (as in Fama and French, 2012), and its upside and downside betas do not differ significantly too. The results for the Japanese momentum portfolios are not reported.
} 
Table 4 reports the Fama-MacBeth (1973) and Hansen's (1982) GMM estimates of risk premiums in the CAPM and DR-CAPM specifications. In case of the CAPM, the beta premium is negative and insignificant, the intercept is highly significant, the adjusted $\mathrm{R}^{2}$ is negative in most cases and the model is rejected by the J-statistics in case with a constant. As in case of the US, the traditional market factor alone cannot explain the returns to the global momentum portfolios. When the relative downside risk is also taken into account, the beta premiums become positive but insignificant, the intercepts become insignificant, and the relative downside beta premiums are highly significant in all cases. The DR-CAPM is never rejected by the J-statistics. The DR-CAPM has high explanatory power for all sets of momentum portfolios, and this explanatory power comes solely from the downside risk component which captures the downside-upside risk asymmetry.

\subsection{GLOBAL SIZE-MOMENTUM PORTFOLIOS}

Table 5 reports the returns, downside and upside betas and the beta asymmetry of 25 global sizemomentum double-sorted portfolios. The portfolio average returns are decreasing with size and increasing with past returns. As a result, all SMB and WML long-short portfolios generate positive returns. The momentum strategy is profitable for all size quintiles, and the momentum effect is stronger for small firms.

The relative downside betas are decreasing with size and increasing with past returns. The relative upside betas, on the contrary, are increasing with size and decreasing with past returns. Small winner stocks have the highest downside risk, the lowest upside risk and the greatest downsideupside risk asymmetry. Big loser stocks have the lowest downside risk, the highest upside risk and the lowest (negative) risk asymmetry. The WML portfolios have positive and statistically significant beta asymmetry for all size quintiles. The SMB portfolios have positive, but insignificant, beta asymmetry. Therefore, this risk asymmetry does not fully explain the size anomaly. 
In figure 4 , I plot predicted versus realized returns of the 25 global size-momentum portfolios where the predictions are made by the traditional CAPM, the three-factor CAPM with the market, size and momentum factors, and the two-beta CAPM. The traditional CAPM has low explanatory power $\left(\mathrm{R}^{2}\right.$ is 0.35$)$, and the market risk premium is negative. The three-factor CAPM explains the returns much better $\left(\mathrm{R}^{2}\right.$ is 0.70$)$, but this result is not surprising because the size and momentum factors are derived from these portfolios themselves. The two-beta CAPM has an even higher explanatory power despite the lower number of factors $\left(\mathrm{R}^{2}\right.$ is 0.75$)$. The asymmetry in betas is aligned well with the portfolio returns.

Table 6 reports the Fama-MacBeth risk premiums in alternative multifactor specifications. In the CAPM (column (1)), the beta premium is negative and the intercept is highly statistically significant. In the DR-CAPM (column (2)), only the relative downside beta premium is significant. This model outperforms the three-factor model (column (3)), where the beta premium is negative and the intercept is significant again. When all risk factors are included (column (4)), the downside risk factor has the highest statistical significance, although the size and momentum factors are significant too. Only the traditional beta is dead.

\subsection{GLOBAL MOMENTUM PORTFOLIOS OF COUNTRY INDICES}

In this section, I consider alternative set of global momentum portfolios, which are formed by sorting country indices instead of individual stocks. Country indices also exhibit momentum, and the WML portfolio of country indices generates high returns which cannot be explained by conventional risk factors (e.g. Richards, 1997; Cenedese et al., 2013).

Table 7 reports the return and risk characteristics of 6 momentum portfolios of country indices and the 6-1 WML portfolio. Both the returns in the local currencies and the returns in the US dollars are increasing with the portfolio rank. According to the Uncovered Equity Parity (Hau and Rey, 2006), equity return differential in the domestic currency should be offset by the depreciation of the 
domestic currency, but this is clearly not the case. Winner portfolios consistently generate higher exchange-rate adjusted returns in excess of the US returns, whereas loser portfolios generate negative excess returns (row 4 in table 7). This violation of the UEP has been documented in Cenedese et al. (2013), and it leads to the global momentum strategies being profitable. Such global momentum strategy WML had an average USD return of about 13 percent per annum in 1984-2013.

The profitability of this momentum strategy cannot be explained by conventional risk measures, like the standard deviation, skewness or market beta because all of them are similar for the 6 portfolios considered. As a result, the WML portfolio has no market risk and low volatility.

As in the previous sections, portfolios with higher rank have higher relative downside betas and lower relative upside betas. Whereas the loser portfolios 1 and 2 have symmetric upside and downside risks, the difference between the downside and upside betas is monotonically increasing with the portfolio rank and it is statistically significant for portfolios 3-6 and the WML portfolio. As a results, although the WML portfolio has the traditional beta of almost zero, it has a positive relative downside beta, a negative relative upside beta and a high beta asymmetry.

The last row of table 7 shows how the index momentum portfolios load on the Fama-French global momentum factor, which is formed by sorting individual stocks ${ }^{7}$. The loadings monotonically increase with the portfolio rank and are highly statistically significant for the loser and winner portfolios. The index-level momentum portfolios and the stock-level momentum portfolios have a similar risk structure and a similar exposure to downside and upside market risks.

Figure 5 plots realized versus predicted returns of the 6 momentum portfolios of country indices, where the predicted returns are estimated using the traditional CAPM and the two-beta CAPM. The CAPM does not explain the returns to the momentum portfolios at all because the CAPM betas and, hence, predicted returns of all portfolios are similar while the realized returns differ significantly. The two-beta CAPM, on the contrary, predicts the returns very well with $\mathrm{R}^{2}$ of 0.91 .

\footnotetext{
${ }^{7}$ The momentum beta is estimated in a two-factor beta-momentum specification.
} 
Table 8 reports the risk premiums in cross-section regressions. As before, the DR-CAPM has a much higher explanatory power than the CAPM, the relative downside beta premium is highly significant whereas the traditional beta premium is not. The estimates of the downside risk premium are similar to the estimates obtained for the global portfolios of individual stocks. Once again, we see that the downside-upside risk asymmetry of momentum portfolios is a global phenomenon and it is priced similarly around the world. It is crucial to account for this asymmetry to fully understand risks of momentum strategies.

\subsection{CURRENCY MOMENTUM PORTFOLIOS}

In addition to various equity momentum strategies, I consider currency momentum strategies as an out-of-sample test. A recent comprehensive study of currency momentum strategies by Menkhoff et al. (2012) provides strong evidence that currency momentum strategies are profitable, particularly for short holding periods ( 1 month), and the profits are mostly generated by the momentum in spot exchange rates rather than in forward discounts. The authors show that the currency momentum returns cannot be fully explained by transaction costs, business cycle risk, liquidity and volatility risks and other traditional risk factors, used in equity and currency literature. They conclude that although the FX markets are more liquid and efficient than the stock markets, "the properties of momentum strategies are fairly similar, which suggests that momentum profits in different asset classes could share a common root".

To be consistent with my previous analysis of the equity market, I consider a currency momentum strategy with 11-month formation period and 1-month holding period. This strategy is one of the most profitable strategies out of 50 strategies considered in Menkhoff et al. (2012). Its average annual return was 6 and 7.6 percent in 1976-2010, depending on whether the spot rate changes or the total excess returns (including the interest rate differentials, or the forward discounts) were used to sort currencies into portfolios and to measure the subsequent returns. Since the spot rate 
changes exhibit greater momentum, I form 5 momentum portfolios by sorting currencies by their preceding spot rate appreciation relative to the US dollar. The winner portfolio includes $1 / 5$ of currencies that have appreciated mostly and the loser portfolio includes $1 / 5$ of currencies that have depreciated mostly.

Panel A of table 9 reports the returns and risk characteristics of the 5 currency momentum portfolios and the WML portfolio. Indeed, the average portfolio return is increasing with the portfolio rank, and the WML portfolio generated a return of 7.82 percent per annum during 19842013. This return is lower compared to the stock market, but still significant and it cannot be explained by the traditional risk measures such as standard deviation, skewness or the market beta.

The relative downside and upside betas exhibit similar patterns as in the stock market. The loser portfolio has the lowest relative downside beta and the highest relative upside beta whereas the winner portfolio has the highest relative downside beta and the lowest relative upside beta. The asymmetry in betas increases with the portfolio rank and it is high and statistically significant for the WML portfolio.

The last row in panel A shows how the currency momentum portfolios load on the global equity momentum factor. Although the loadings are not very high, they have predictable signs and are statistically significant for the winner, loser and WML portfolios. Therefore, momentum portfolios in different asset markets have a common component. My findings suggest that the relative downside risk can explain this common component because all momentum portfolios have similar exposure to the downside risk.

Panel B of table 9 shows the Fama-MacBeth and the efficient GMM risk premiums in the crosssection regressions. Since the intercepts are insignificant in all specifications, they are dropped out. As before, the traditional CAPM has low explanatory power and the beta premium is negative. The DR-CAPM has higher explanatory power, which comes predominantly from the downside-risk 
component. The estimates of the relative downside beta premium are all statistically significant and similar in magnitude to the estimates obtained for the stock market.

\subsection{ALL MOMENTUM PORTFOLIOS TOGETHER}

In this section, I show that the asymmetric exposure to the downside and upside market risks is a unifying explanation of returns to momentum portfolios in different markets. I analyze all portfolios studied previously as a single cross-section. I have 48 portfolios in total: 10 US portfolios, 5 global, 5 European, 5 Asian-Pacific and 5 North-American portfolios of stocks, 6 global portfolios of country indices, 5 currency portfolios and 7 corresponding WML portfolios. The sample period is restricted November 1990 - August 2013 since some portfolios are not available prior to that period.

The correlation matrix for returns of the 7 WML portfolios is presented in table 10. Generally, all portfolios have positive and statistically significant correlations with each other, but the correlation coefficient vary. The highest correlations are observed between portfolios of individual stocks (up to 0.9), and the lowest correlation are observed for the portfolios of country indices and currencies (0.15-0.3). Therefore, global momentum portfolios perform differently over time despite the similarities in their relative upside and downside betas.

In figure 6, I plot predicted and realized returns of the 48 momentum portfolios. In the left-handside figure, the predictions are made by the CAPM. There are three clear clusters of momentum portfolios. The 7 portfolios in the oval cluster are the WML portfolios. The 5 portfolios in the rhombus cluster are the currency portfolios. The portfolios in the right-angle cluster are equity portfolios of stocks and country indices. Within each cluster, all predicted returns are similar whereas the actual returns vary significantly. The CAPM is not able to explain the momentum portfolio returns.

When the DR-CAPM is used to predict returns (the right-hand-side figure), all portfolios are scattered around the 45 -degree line with $\mathrm{R}^{2}$ of $57 \%$. The currency portfolios are closer to the origin 
and the equity portfolios are further from it. But there are no visible clusters, and all WML portfolios are close to the 45-degree line. Therefore, the DR-CAPM has a high explanatory power for the single cross-section of 48 momentum portfolio.

Table 11 reports the Fama-MacBeth estimates of cross-section regressions with alternative specifications. The traditional CAPM is rejected because the market risk premium is statistically insignificant in case with a constant and the $\mathrm{R}^{2}$ is negative in case of no constant. When the market and momentum factors are included (column (3)), both are significant, the intercept becomes insignificant, and the adjusted $\mathrm{R}^{2}$ increases from 16 to 49 percent. Therefore, inclusion of the momentum risk factor improves the explanatory power of the CAPM dramatically.

The DR-CAPM has an even higher adjusted $\mathrm{R}^{2}$, and the both premiums are statistically significant, whereas the intercept is not ${ }^{8}$. The relative downside beta premium is $3-4$ percent per month which can be considered a unifying estimate across different markets around the world. Most importantly, inclusion of the momentum factor (column (5)) does not improve the explanatory power of the DR-CAPM, and the momentum factor itself is statistically insignificant. After controlling for the downside-upside risk asymmetry, the momentum factor becomes redundant.

\subsection{US REVERSAL PORTFOLIOS}

As an extension, I analyze reversal portfolios which have also been shown to generate abnormal returns. I consider short-term and long-term reversal portfolios of US individual stocks. The shortterm reversal portfolios are sorted by the previous month return and held for one month. The longterm reversal portfolios are sorted by the previous five-year return and held for one month.

There is a strong short-term and a moderate long-term reversal effect. Stocks which had higher prior return perform worse in the subsequent month. The loser-minus-winner one-month reversal portfolio had an average return of 19 percent per annum during 1984-2013. The loser-minus-winner

\footnotetext{
${ }^{8}$ The intercepts in specifications (3)-(5) are statistically insignificant and can easily be dropped out without affecting the results.
} 
five-year reversal portfolio generated an average return of 6 percent per annum during the same period.

Figures 7 and 8 plot the predicted versus realized returns of the short-term and long-term reversal portfolios, respectively. In the left panels, the prediction is made by the traditional CAPM, whereas the two-beta CAPM is used in the right panels. As in the case of momentum portfolios, the traditional CAPM has weak or no explanatory power for the cross-section of reversal portfolios. But the two-beta CAPM performs well again (the $\mathrm{R}^{2}$ is between 58 and 80 percent).

In the cross-section tests (table 10), the relative downside beta premium is lower in magnitude than in the case of momentum portfolios, but still statistically significant. In case of short-term reversal, the beta premium is also significant. In case of long-term reversal, only the downside risk premium is weakly significant. The downside-upside risk asymmetry explains the returns to the reversal portfolios as well. The past loser portfolios generally have higher relative downside betas and lower relative upside betas (greater beta asymmetry) than past winner portfolios and require risk premiums.

\section{CONCLUSION}

Momentum strategies generate high returns with insignificant overall market risk. Therefore, the momentum return is either evidence for market inefficiency, or a compensation for another risk factor. In this paper, I provide a novel risk-based explanation for momentum returns. I show that once we separate the overall market risk into the upside and downside risks, the momentum strategies appear to have asymmetric risk profile: they are exposed to the downside risk, but hedge against the upside risk. Since the upside and downside risks are priced differently, the momentum return is a compensation for this risk asymmetry.

I consider US, global and regional momentum and reversal portfolios of individual stocks and global momentum portfolios of country indices and currencies. I show that the asymmetry in upside 
and downside market risks explains all cross-sections of momentum portfolio returns well. Past loser portfolios have lower downside risk and higher upside risk, whereas past winner portfolios have higher downside risk and lower upside risk and, hence, greater downside-upside risk asymmetry. For any set of momentum portfolios, the risk asymmetry is monotonically increasing with portfolio rank. The downside-risk CAPM explains the cross-section of momentum returns much better than the traditional CAPM. The estimates of the relative downside beta premium are always statistically significant and similar in magnitude to the estimates obtained for other asset markets. Therefore, the momentum return is not anomalous, but a compensation for the asymmetric upside and downside market risks. 


\section{REFERENCES}

1. Ang, A., and J. Chen, 2002, Asymmetric correlations of equity portfolios, Journal of Financial Economics, 63, 443-494.

2. Ang, A., J. Chen and Y. Xing, 2001, Downside risk and the momentum effect, NBER Working paper \#8643.

3. Ang, A., J. Chen and Y. Xing, 2006, Downside risk, Review of Financial Studies, 19(4), 11911239.

4. Asness, Clifford, John M. Liew, and Ross L. Stevens, 1997, Parallels between the crosssectional predictability of stock and country returns, Journal of Portfolio Management 23, 79-87.

5. Asness, Clifford, Toby J. Moskowitz, and Lasse Heje Pedersen, 2013, Value and momentum everywhere, Journal of Finance 58, 929-895.

6. Bawa, V. S., and E. B. Lindenberg, 1977, Capital market equilibrium in a mean-lower partial moment framework, Journal of Financial Economics, 5, 189-200.

7. Burnside, C., M. Eichenbaum, I. Kleshchelski, and S. Rebelo, 2011, Do Peso problems explain the returns to carry trades? Review of Financial Studies, 24, 853-891.

8. Cenedese, G., R. Payne, L. Sarno, and G. Valente, 2013, What do stock markets tell us about exchange rates?, working paper.

9. Cochrane, John H., 2005. Asset pricing. Princeton University Press.

10. Daniel, K. and T. Moskowitz, 2013, Momentum crashes, working paper, Columbia Business School, University of Chicago.

11. De Bondt, Werner F. M., and Richard H. Thaler, 1987, Further evidence on investor overreactionand stock market seasonality, Journal of Finance 42, 557-581.

12. Dobrynskaya, V., 2014, Downside market risk of carry trades, Review of Finance, forthcoming.

13. Fama, Eugene F., and Kenneth R. French, 1996, Multifactor explanations of asset pricing anomalies, Journal of Finance 51, 55-84. 
14. Fama, Eugene F., and Kenneth R. French, 2012, Size, value, and momentum in international stock returns, Journal of Financial Economics 105, 457-472.

15. Hansen, L.P., 1982, Large sample properties of Generalized Method of Moments estimators, Econometrica, 50(4), 1029-1054.

16. Hau, H., and H. Rey, 2006, Exchange rates, equity prices, and capital flows, Review of Financial Studies, 19, 273-317.

17. Jegadeesh, N., and S. Titman, 1993, Returns to buying winners and selling losers: Implications for stock market efficiency, Journal of Finance, 48, 65-91.

18. Lettau, M., M. Maggiori and M. Weber, 2014, Conditional risk premia in currency markets and other asset classes, Journal of Financial Economics, forthcoming.

19. Longin, F., and B. Solnik, 1995, Is the correlation in international equity returns constant: 19601990? Journal of International Money and Finance 14, 3-26.

20. Lustig, H., N. Roussanov, and A. Verdelhan, 2011, Common risk factors in currency markets, Review of Financial Studies, 24, 3731-3777.

21. Markowitz, H., 1959, Portfolio selection. Yale University Press, New Haven, CT.

22. Menkhoff, L., L. Sarno, M. Schmeling, A. Schrimpf, 2012, Currency momentum strategies, Journal of Financial Economics 106, 660-684.

23. Okunev, John, and Derek White, 2003, Do momentum-based strategies still work in foreign currency markets? Journal of Financial and Quantitative Analysis 38, 425-447.

24. Richards, A.J., 1997, Winner-loser reversals in national stock market indices: Can they be explained? Journal of Finance, LII (5), 2129-2144.

25. Rouwenhorst, K.G., 1998, International momentum strategies, Journal of Finance 53,267-284.

26. Rouwenhorst, K.G., 1999, Local return factors and turnover in emerging stock markets, Journal of Finance, 54, 1439-1464.

27. Roy, A. D., 1952, Safety first and the holding of assets, Econometrica, 20, 431-449. 
Figure 1. Relative upside and downside risks of US momentum portfolios

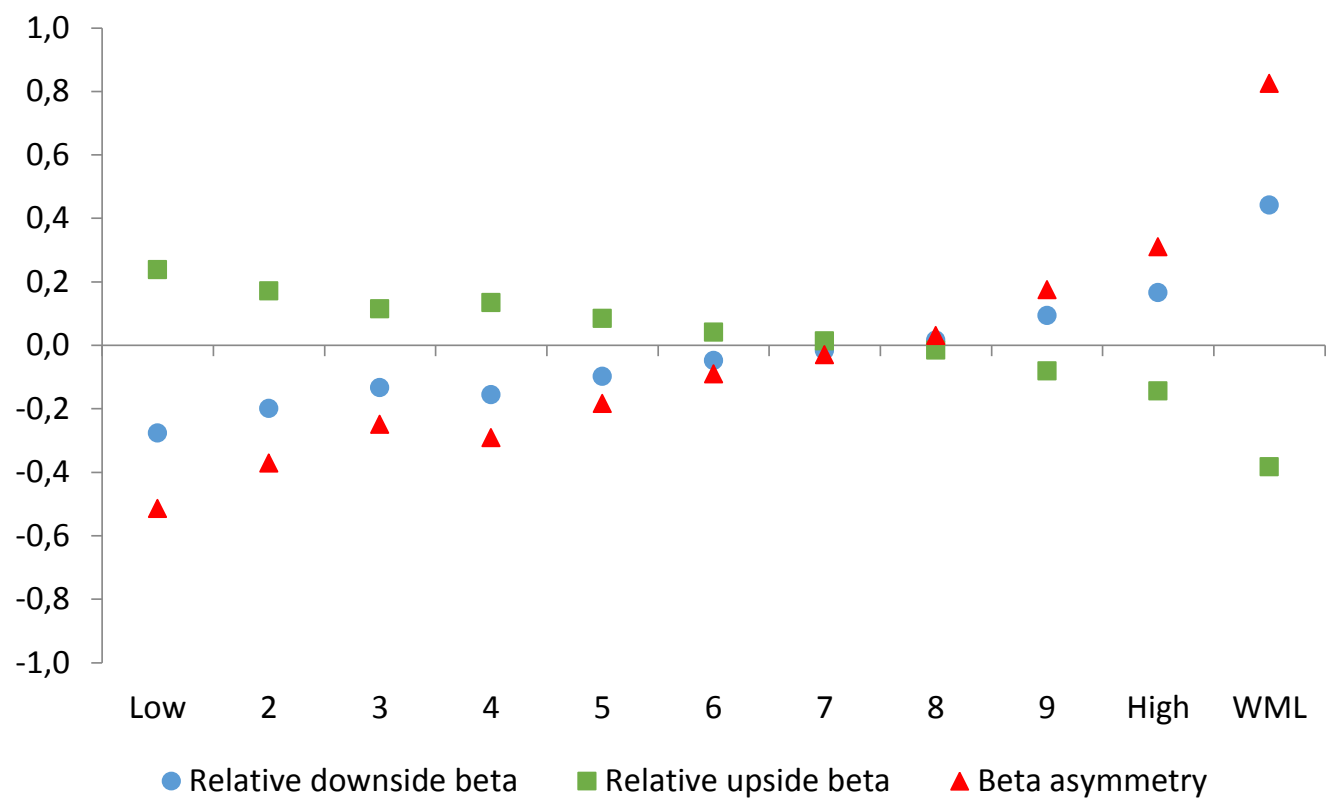

The figure shows the OLS estimates of relative downside and upside betas and beta asymmetry $\left(\beta^{-}-\beta^{+}\right)$of 10US valueweighted momentum portfolios, formed by sorting stocks at time $\mathrm{t}$ by their total return in time $\mathrm{t}-12$ to $\mathrm{t}-2$, and the winnerminus-loser (WML) portfolio. January 1927 - July 2013. 
Figure 2. Predicted versus realized returns of US momentum portfolios

\section{CAPM}

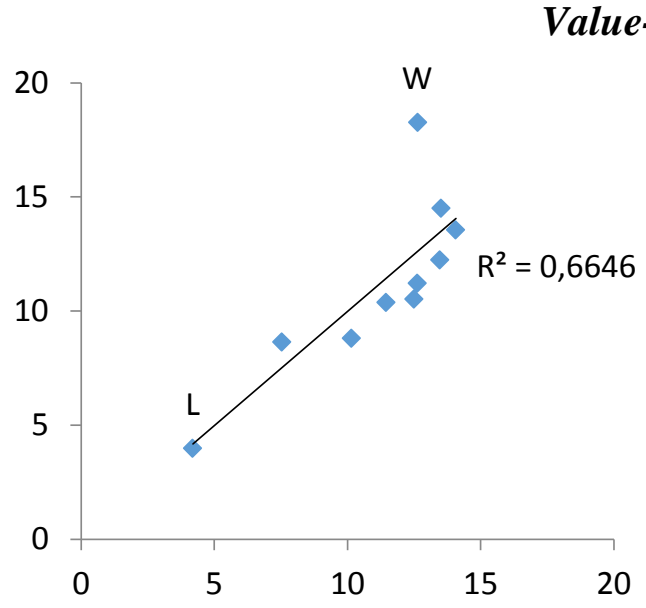

\section{Two-beta CAPM}

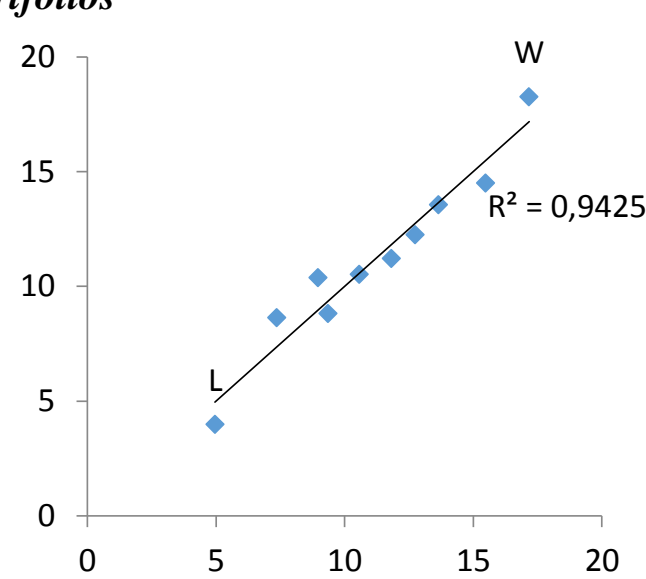

Equal-weighted portfolios
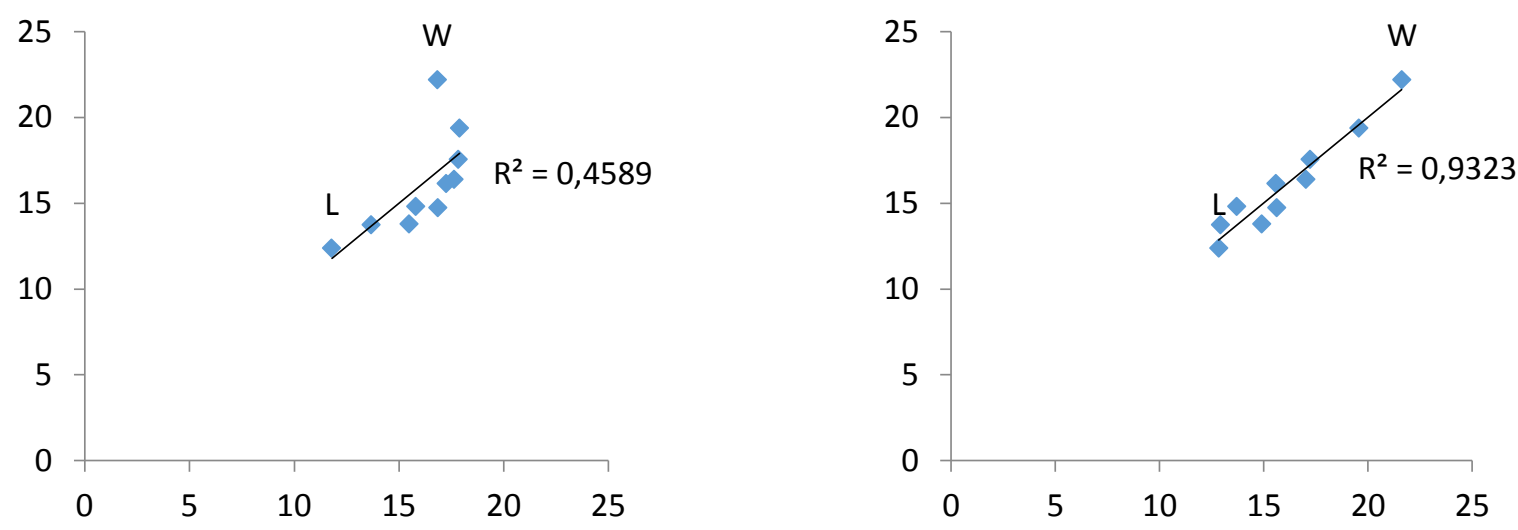

The figures show predicted (on the horizontal axis) versus realized (on the vertical axis) returns of 10 US momentum portfolios, formed by sorting stocks at time t by their total return in time $\mathrm{t}-12$ to $\mathrm{t}-2$. The predictions are made assuming the CAPM (left-hand side) and the two-beta CAPM (right-hand side) using the OLS estimates.January 1927 - July 2013. 
Figure 3. Predicted versus realized returns of global and regional momentum portfolios: Two-beta CAPM
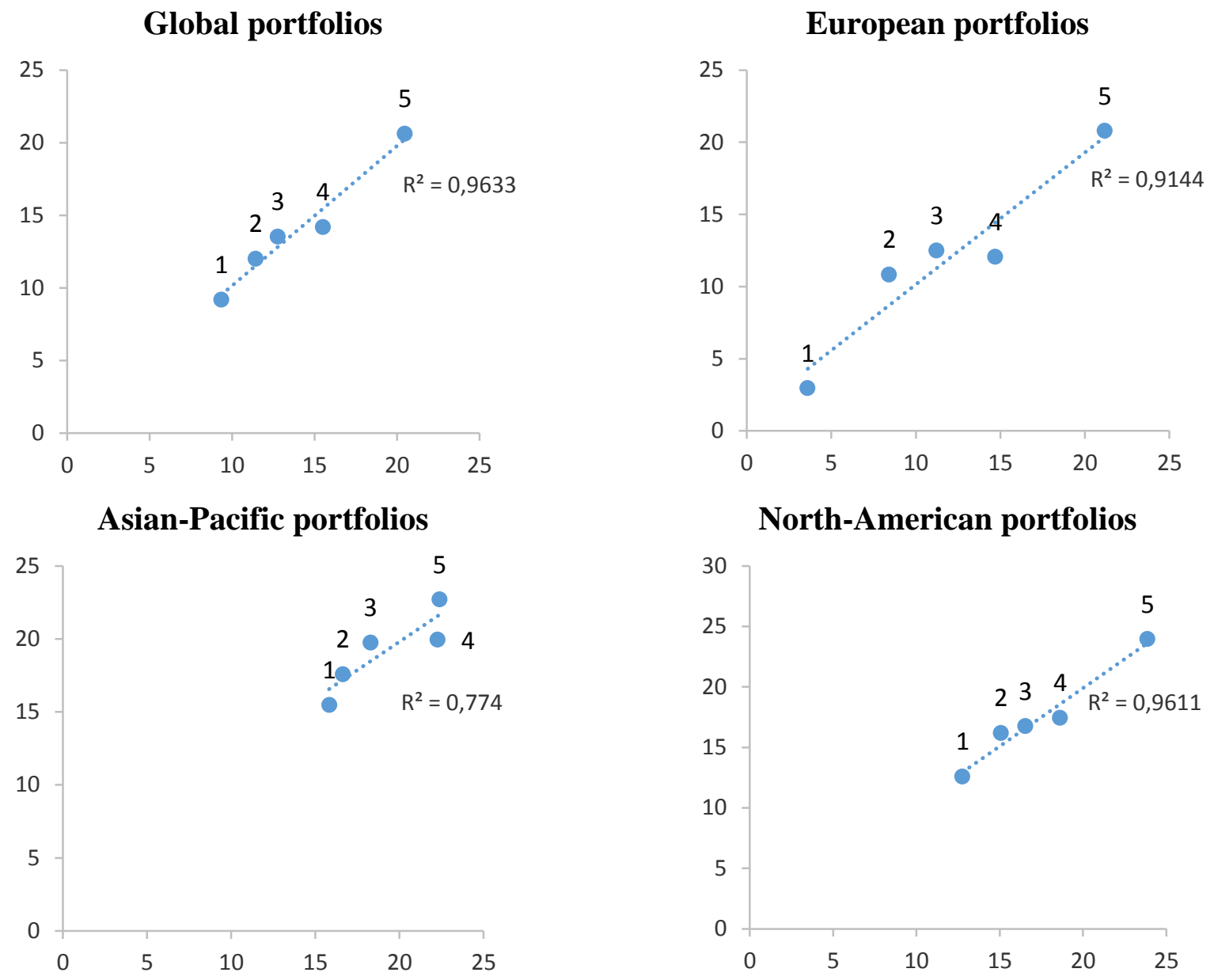

The figures show predicted (on the horizontal axis) versus realized (on the vertical axis) returns of global and regional momentum portfolios, formed by sorting stocks in the corresponding region at time $\mathrm{t}$ by their total return in time $\mathrm{t}-12$ to $\mathrm{t}-$ 2. The prediction is made assuming the two-beta CAPM using the OLS estimates. Nov 1990 - Aug 2013. 
Figure 4. Predicted versus realized returns of 25 global size-momentum portfolios

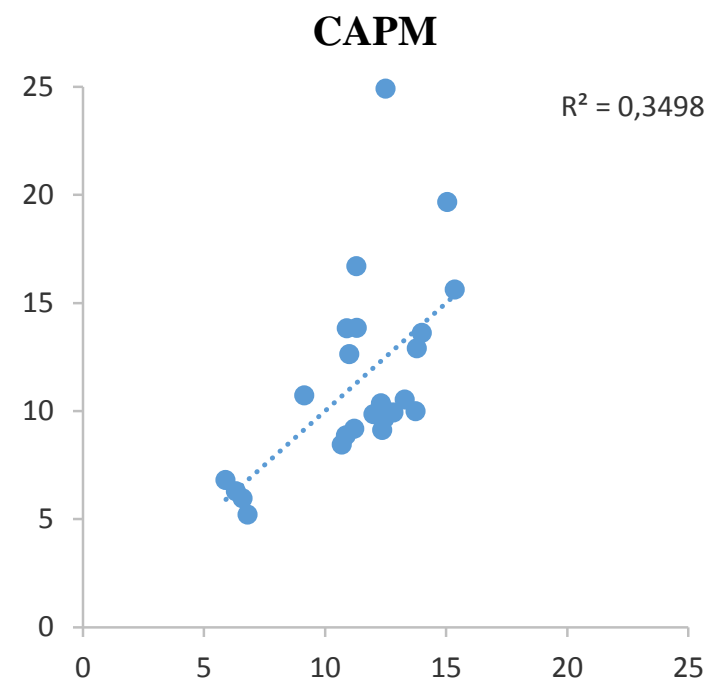

3-factor CAPM with the market, size and momentum factors

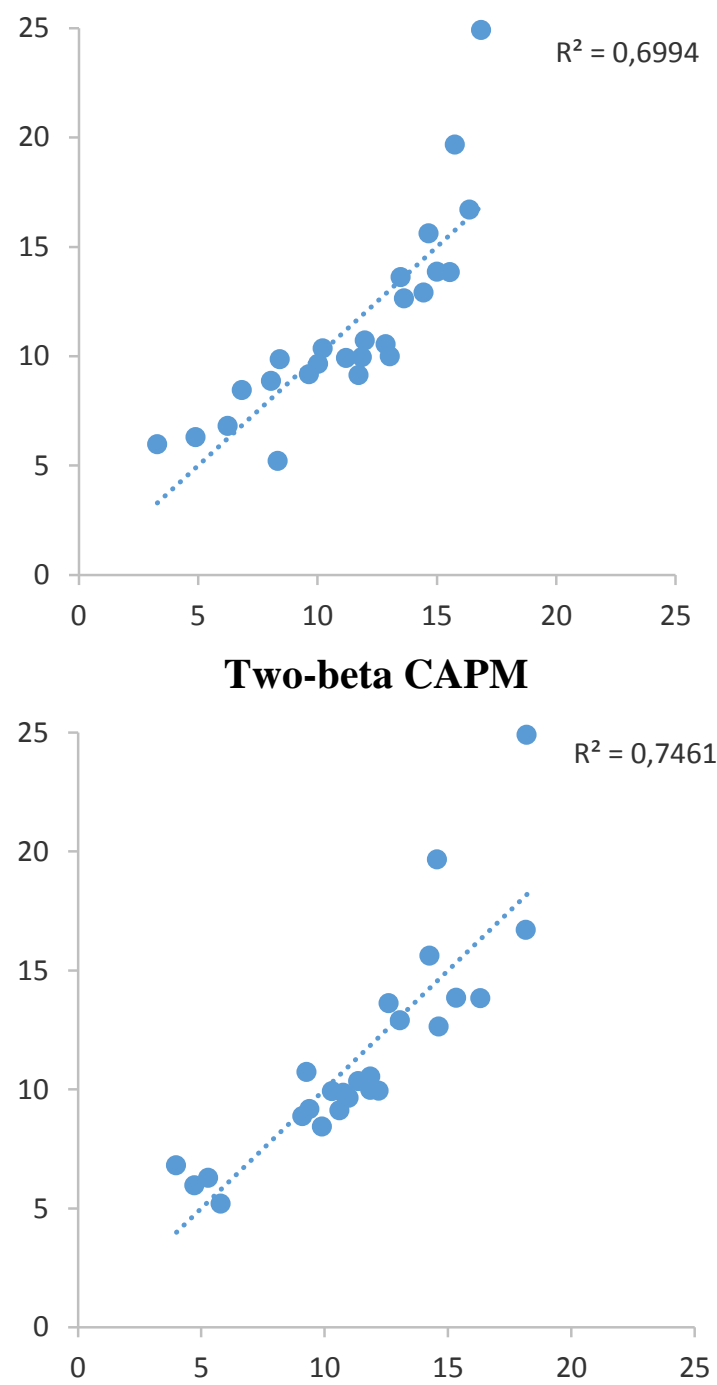

The figures show predicted (on the horizontal axis) versus realized (on the vertical axis) returns of 25 global doublesorted size-momentum portfolios. The predictions are made using alternative factor models and OLS estimates. Nov 1990 - Aug 2013. 
Figure 5. Predicted versus realized returns of momentum portfolios of country indices

\section{CAPM}

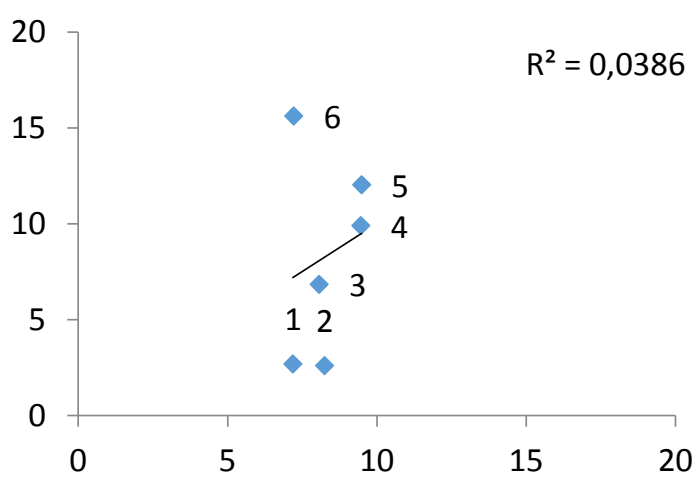

\section{Two-beta CAPM}

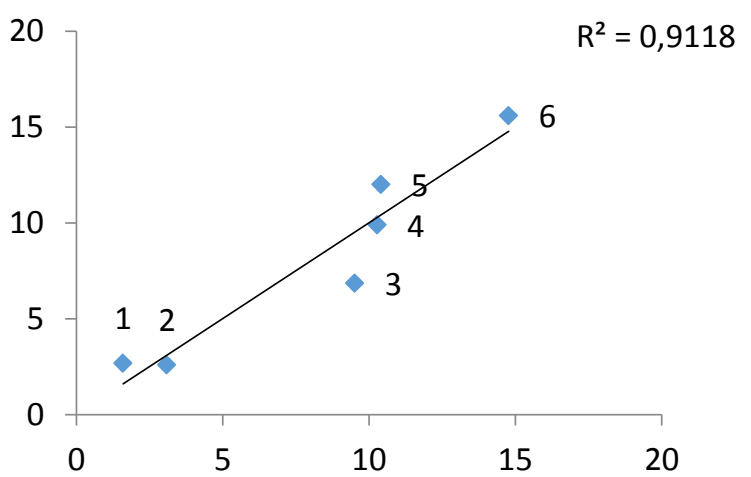

The figures show predicted (on the horizontal axis) versus realized (on the vertical axis) returns of 6 global momentum portfolios, formed by sorting 40 country indices at time $t$ by their total return in time t-12 to t-2The predictions are made assuming the CAPM (left-hand side) and the two-beta CAPM (right-hand side) using the OLS estimates. Jan 1984 - Aug 2013. 


\section{Figure 6. Predicted versus realized returns of $\mathbf{4 8}$ global and regional momentum portfolios}

\section{CAPM}

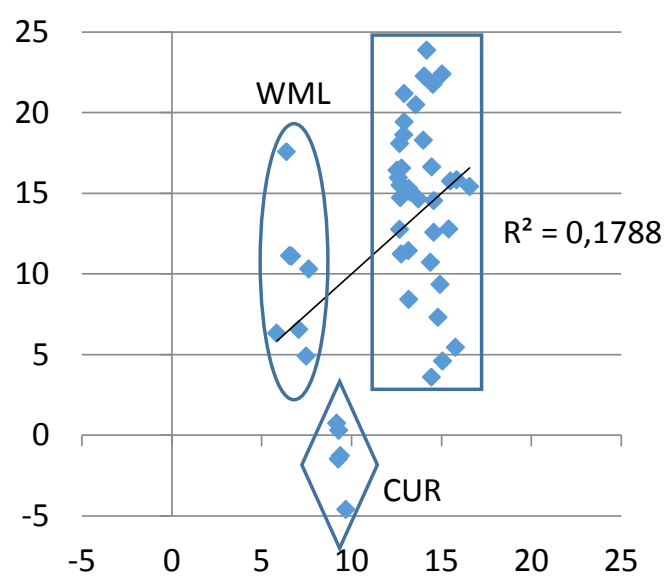

\section{DR-CAPM}

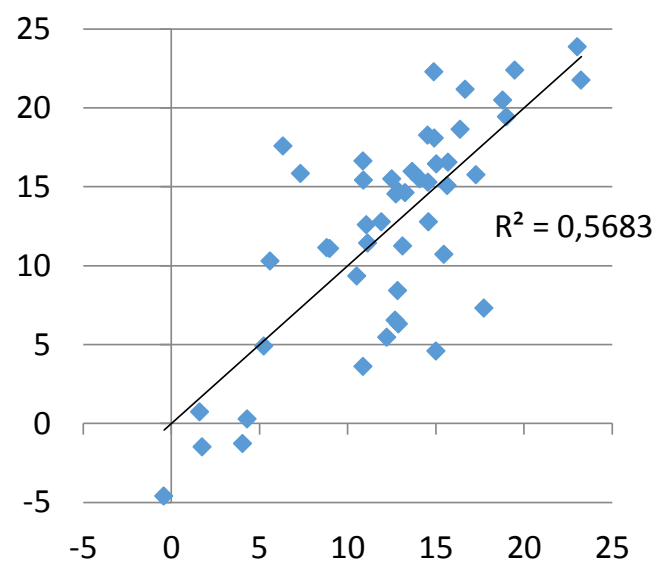

The figures show predicted (on the horizontal axis) versus realized (on the vertical axis) returns of 48 global and regional momentum portfolios (10 US portfolios, 5 global, 5 European, 5 Asian-Pacific and 5 North-American portfolios of stocks, 6 portfolios of country indices and 5 currency portfolios, and 7 corresponding WML portfolios). All portfolios are formed by sorting base assets at time $t$ by their total return in time $t-12$ to $t-2$. The predictions are made assuming the CAPM (left-hand side) and the DR-CAPM (right-hand side) using the OLS estimates. Nov 1990 - Aug 2013. 
Figure 7. Predicted versus realized returns of US short-term reversal portfolios

\section{CAPM}

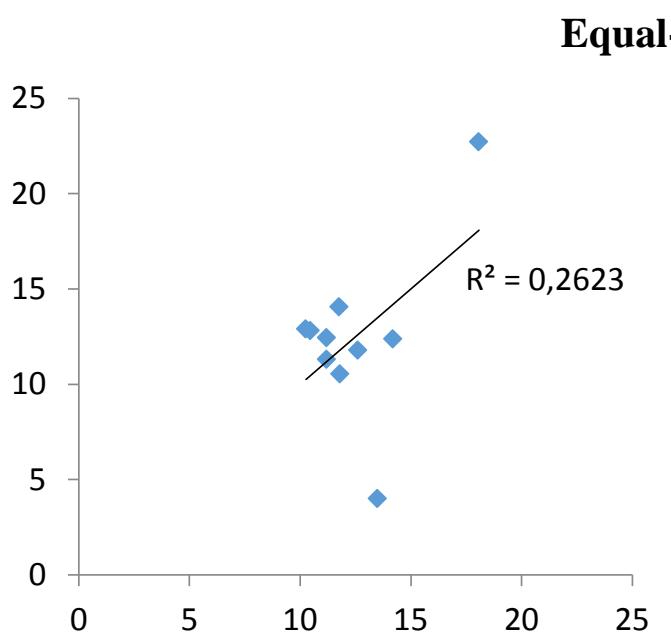

\section{Two-beta CAPM}

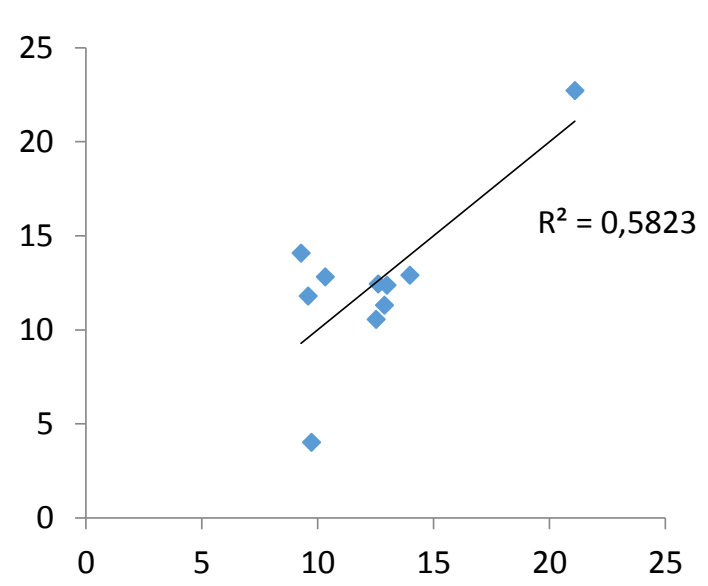

Value-weighted
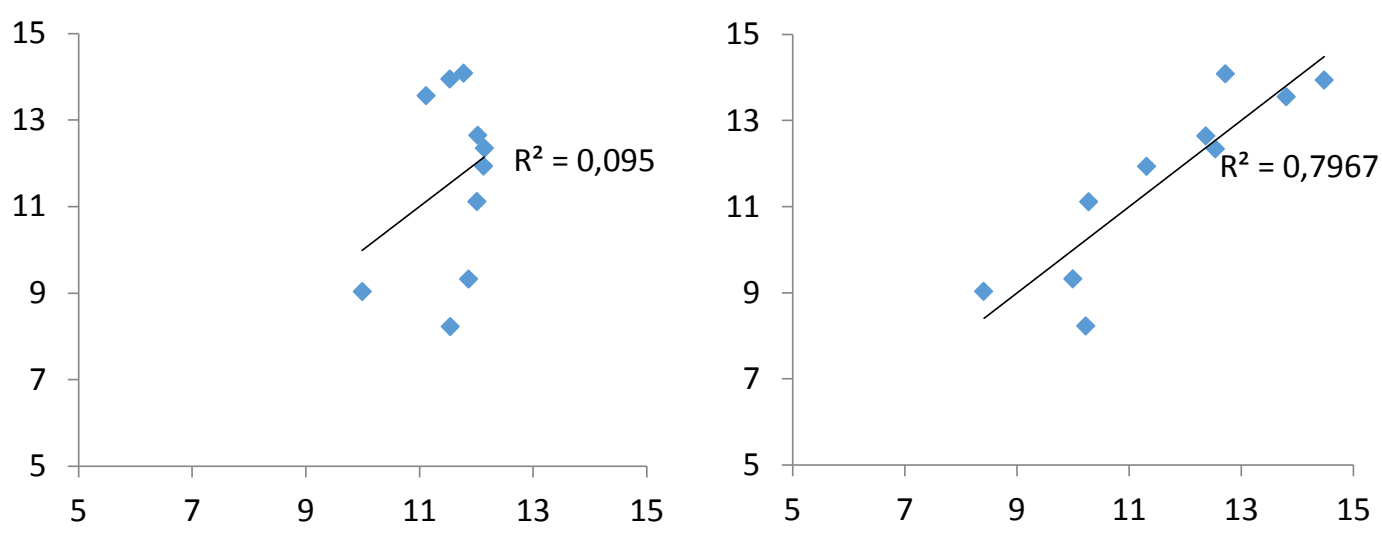

The figures show predicted (on the horizontal axis) versus realized (on the vertical axis) returns of 10 US short-term reversal portfolios, formed by sorting individual stocks in month $\mathrm{t}$ by their return in month $\mathrm{t}-1$. The predictions are made assuming the CAPM (left-hand side) and the two-beta CAPM (right-hand side) using the OLS estimates. Jan 1984 - Jul 2013. 
Figure 8. Predicted versus realized returns of 5 US long-term reversal portfolios

\section{CAPM}

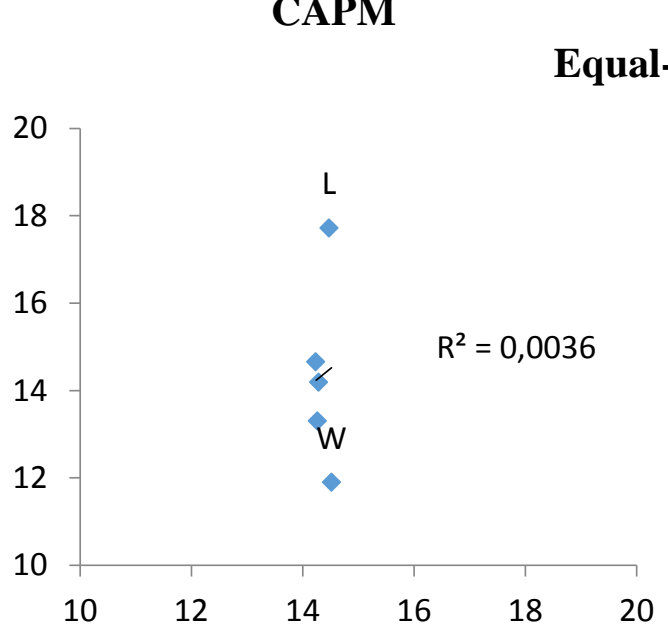

\section{Two-beta CAPM}

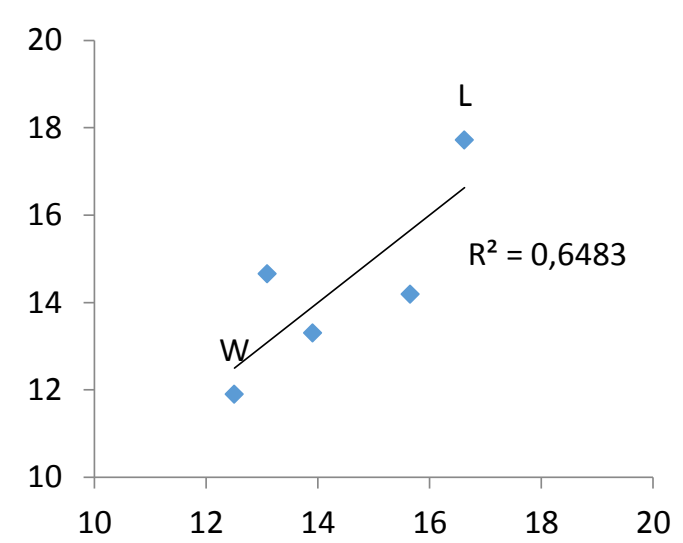

\section{Value-weighted}
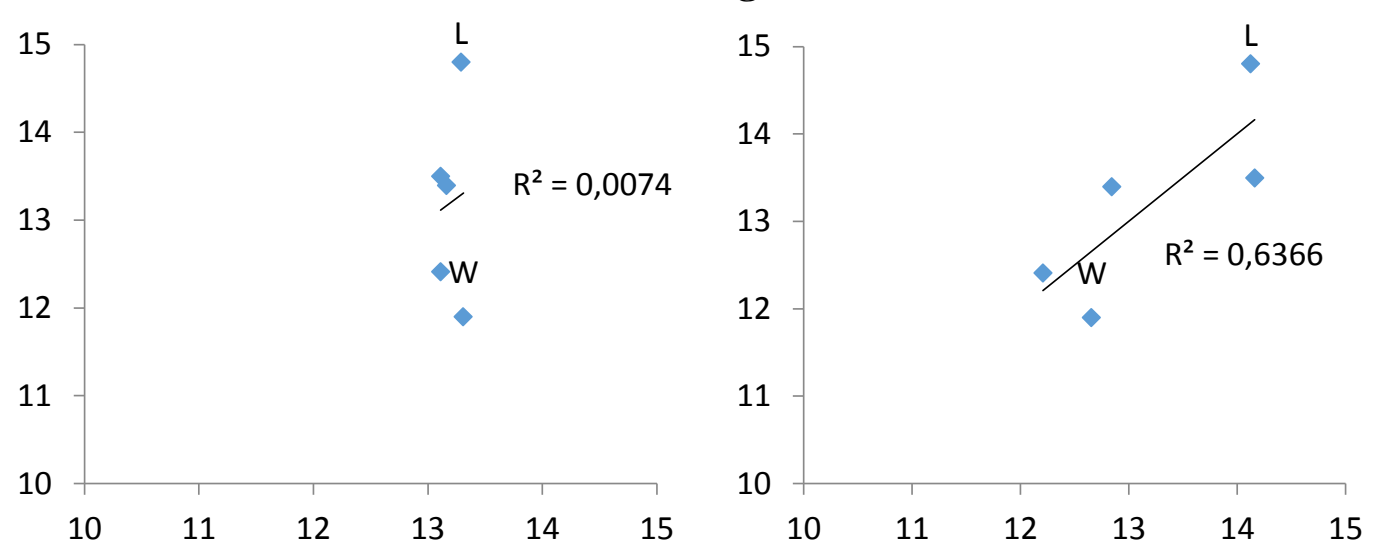

The figures show predicted (on the horizontal axis) versus realized (on the vertical axis) returns of 5 US long-term reversal portfolios, formed by sorting individual stocks in month $\mathrm{t}$ by their return in the preceding 5 -year period. The predictions are made assuming the CAPM (left-hand side) and the two-beta CAPM (right-hand side) using the OLS estimates. Jan 1984 - Jul 2013. 


\section{Table 1. Return and risk characteristics of US momentum portfolios}

The table reports return and risk characteristics of 10 value-weighted and 10 equal-weighted US momentum portfolios, formed by sorting NYSE, AMEX, and NASDAQ stocks at time $\mathrm{t}$ by their total return in time $\mathrm{t}-12$ to $\mathrm{t}-2$, and the corresponding winner-minus-loser (WML) portfolios. The returns are annualized and expressed in percent. The reported betas are the OLS time-series estimates. The US market index serves as a proxy for the market portfolio. The momentum factor is the corresponding WML portfolio. T-statistics are in brackets, t-statistics are calculated using NW heteroskedasticity consistent standard errors. Jan 1927 - July 2013.

\begin{tabular}{|c|c|c|c|c|c|c|c|c|c|c|c|}
\hline & Low & 2 & 3 & 4 & 5 & 6 & 7 & 8 & 9 & High & WML \\
\hline & \multicolumn{11}{|c|}{ Value-weighted } \\
\hline Average return $(\%$ pa) & 3.99 & 8.64 & 8.81 & 10.37 & 10.52 & 11.22 & 12.24 & 13.56 & 14.50 & 18.26 & 14.27 \\
\hline Standard deviation & 117.98 & 98.05 & 84.72 & 77.30 & 71.82 & 69.90 & 66.74 & 64.74 & 68.33 & 78.62 & 95.44 \\
\hline Skewness & 1.82 & 1.79 & 1.48 & 1.46 & 1.24 & 0.69 & 0.12 & 0.00 & -0.32 & -0.50 & -2.44 \\
\hline Kurtosis & 16.32 & 20.15 & 18.70 & 17.40 & 17.33 & 11.77 & 7.36 & 4.58 & 3.62 & 2.15 & 18.29 \\
\hline \multirow[t]{2}{*}{ Market beta $(\beta)$} & 1.55 & 1.34 & 1.18 & 1.10 & 1.03 & 1.03 & 0.97 & 0.94 & 0.97 & 1.02 & -0.52 \\
\hline & [18.34] & [16.16] & {$[17.58]$} & [23.61] & [21.37] & [35.25] & {$[45.72]$} & {$[45.46]$} & [29.33] & {$[15.14]$} & {$[-3.54]$} \\
\hline $\begin{array}{l}\text { Relative downside beta } \\
\left(\beta^{-}-\beta\right)\end{array}$ & -0.28 & -0.20 & -0.13 & -0.16 & -0.10 & -0.05 & -0.02 & 0.02 & 0.09 & 0.17 & 0.44 \\
\hline $\begin{array}{l}\text { Relative upside beta } \\
\left(\beta^{+}-\beta\right)\end{array}$ & 0.24 & 0.17 & 0.12 & 0.13 & 0.08 & 0.04 & 0.01 & -0.01 & -0.08 & -0.14 & -0.38 \\
\hline Beta asymmetry & -0.51 & -0.37 & -0.25 & -0.29 & -0.18 & -0.09 & -0.03 & 0.03 & 0.18 & 0.31 & 0.83 \\
\hline$\left(\beta^{-}-\beta^{+}\right)$ & {$[-2.67]$} & {$[-1.98]$} & {$[-1.76]$} & {$[-3.33]$} & {$[-1.45]$} & {$[-1.54]$} & {$[-0.55]$} & {$[0.71]$} & {$[2.23]$} & {$[2.37]$} & [2.64] \\
\hline \multirow[t]{3}{*}{ US momentum beta } & -0.63 & -0.39 & -0.28 & -0.19 & -0.14 & -0.05 & 0.02 & 0.10 & 0.17 & 0.37 & 1.00 \\
\hline & {$[-33.47]$} & {$[-17.06]$} & {$[-12.40]$} & {$[-12.04]$} & {$[-5.45]$} & {$[-2.72]$} & {$[1.46]$} & {$[7.02]$} & [10.88] & [19.67] & \\
\hline & \multicolumn{11}{|c|}{ Equal-weighted } \\
\hline Average return (\% pa) & 12.38 & 13.73 & 13.78 & 14.80 & 14.73 & 16.15 & 16.39 & 17.56 & 19.38 & 22.18 & 9.80 \\
\hline Standard deviation & 134.99 & 109.70 & 94.74 & 91.40 & 83.32 & 79.89 & 77.64 & 76.57 & 77.59 & 89.20 & 93.15 \\
\hline Skewness & 2.85 & 3.12 & 2.08 & 2.53 & 1.74 & 1.44 & 1.07 & 0.94 & 0.10 & 0.11 & -4.25 \\
\hline Kurtosis & 22.15 & 31.71 & 20.01 & 24.76 & 20.35 & 16.11 & 14.51 & 13.55 & 5.80 & 5.71 & 38.34 \\
\hline \multirow[t]{2}{*}{ Market beta $(\beta)$} & 1.59 & 1.43 & 1.28 & 1.25 & 1.16 & 1.13 & 1.09 & 1.08 & 1.07 & 1.16 & -0.43 \\
\hline & [16.26] & [14.09] & [19.86] & [15.89] & [21.45] & [24.08] & [26.40] & {$[22.62]$} & [28.40] & {$[17.77]$} & {$[-3.08]$} \\
\hline $\begin{array}{l}\text { Relative downside beta } \\
\left(\beta^{-}-\beta\right)\end{array}$ & -0.38 & -0.32 & -0.18 & -0.23 & -0.11 & -0.10 & -0.03 & -0.01 & 0.09 & 0.15 & 0.53 \\
\hline $\begin{array}{l}\text { Relative upside beta } \\
\left(\beta^{+}-\beta\right)\end{array}$ & 0.33 & 0.28 & 0.16 & 0.20 & 0.10 & 0.09 & 0.02 & 0.01 & -0.08 & -0.13 & -0.46 \\
\hline Beta asymmetry & -0.71 & -0.60 & -0.34 & -0.42 & -0.21 & -0.19 & -0.05 & -0.02 & 0.17 & 0.28 & 0.99 \\
\hline$\left(\beta^{-}-\beta^{+}\right)$ & {$[-2.69]$} & {$[-2.15]$} & {$[-2.10]$} & {$[-2.23]$} & {$[-1.50]$} & {$[-1.64]$} & {$[-0.47]$} & {$[-0.16]$} & {$[1.74]$} & {$[1.81]$} & [2.81] \\
\hline \multirow[t]{2}{*}{ US momentum beta } & -0.83 & -0.50 & -0.34 & -0.29 & -0.21 & -0.14 & -0.07 & 0.00 & 0.06 & 0.17 & 1.00 \\
\hline & {$[-24.65]$} & {$[-12.00]$} & {$[-15.84]$} & {$[-9.36]$} & {$[-7.47]$} & {$[-6.64]$} & {$[-3.52]$} & {$[-0.15]$} & {$[2.53]$} & [4.91] & \\
\hline
\end{tabular}




\section{Table 2. Cross-section regressions for US momentum portfolios}

The table reports the Fama-MacBeth and efficient GMM estimates of risk premiums (in percent per month) obtained for 10 value-weighted and 10 equal-weighted US momentum portfolios. The US market index serves as a proxy for the market portfolio. T-statistics are in brackets, t-statistics are calculated using NW heteroskedasticity consistent standard errors. J statistics for the over-identifying restrictions is also reported. P-value for J statistics is in parentheses. Jan $1927-$ July 2013.

\begin{tabular}{|c|c|c|c|c|c|c|c|c|}
\hline & \multicolumn{4}{|c|}{ Fama-MacBeth } & \multicolumn{4}{|c|}{ GMM } \\
\hline & \multicolumn{2}{|c|}{ CAPM } & \multicolumn{2}{|c|}{ DR-CAPM } & \multicolumn{2}{|c|}{ CAPM } & \multicolumn{2}{|c|}{ DR-CAPM } \\
\hline & \multicolumn{8}{|c|}{ Value-weighted } \\
\hline \multirow[t]{2}{*}{ Beta $(\beta)$} & 0.53 & -1.35 & 0.75 & -0.19 & 1.11 & -0.81 & 0.71 & 0.12 \\
\hline & {$[2.96]$} & {$[-3.71]$} & {$[4.20]$} & {$[-0.51]$} & [7.11] & {$[-2.31]$} & [3.93] & {$[0.15]$} \\
\hline \multirow[t]{2}{*}{ Relative downside beta $\left(\beta^{-}-\beta\right)$} & & & 3.11 & 2.07 & & & 4.29 & 3.03 \\
\hline & & & {$[6.08]$} & [3.62] & & & [2.21] & [2.04] \\
\hline \multirow[t]{2}{*}{ Constant } & & 2.15 & & 0.99 & & 1.57 & & 0.65 \\
\hline & & {$[6.37]$} & & {$[2.95]$} & & {$[4.76]$} & & [0.79] \\
\hline $\mathrm{R}^{2}$ adj & -0.66 & 0.62 & 0.80 & 0.93 & & & & \\
\hline \multirow[t]{3}{*}{ J-stat } & & & & & 20.49 & 22.57 & 4.57 & 4.39 \\
\hline & & & & & $(0.02)$ & $(0.00)$ & $(0.80)$ & $(0.73)$ \\
\hline & \multicolumn{8}{|c|}{ Equal-weighted } \\
\hline \multirow[t]{2}{*}{$\operatorname{Beta}(\beta)$} & 0.83 & -0.98 & 1.06 & 0.65 & 1.26 & 0.23 & 1.06 & 0.98 \\
\hline & [4.04] & {$[-2.28]$} & {$[5.18]$} & {$[1.34]$} & {$[7.28]$} & {$[0.62]$} & {$[4.78]$} & [1.36] \\
\hline \multirow[t]{2}{*}{ Relative downside beta $\left(\beta^{-}-\beta\right)$} & & & 2.25 & 1.90 & & & 2.27 & 2.19 \\
\hline & & & {$[5.59]$} & [4.10] & & & [2.84] & {$[2.25]$} \\
\hline \multirow[t]{2}{*}{ Constant } & & 2.25 & & 0.48 & & 0.84 & & 0.10 \\
\hline & & {$[5.18]$} & & {$[1.02]$} & & {$[2.37]$} & & [0.13] \\
\hline $\mathrm{R}^{2}$ adj & -1.13 & 0.39 & 0.90 & 0.91 & & & & \\
\hline \multirow[t]{2}{*}{ J-stat } & & & & & 19.09 & 25.67 & 1.38 & 1.72 \\
\hline & & & & & $(0.02)$ & $(0.00)$ & $(0.99)$ & $(0.97)$ \\
\hline
\end{tabular}




\section{Table 3. Return and risk characteristics of global momentum portfolios}

The table reports return and risk characteristics of 5 global equal-weighted momentum portfolios (panel A) and 5 regional equal-weighted momentum portfolios (panels B-D), and the corresponding winner-minus-loser (WML) momentum portfolios. All portfolios are formed by sorting individual stocks in the corresponding region at time $t$ by their total return in time t-12 to t-2. All returns are converted to USD, annualized and expressed in percent. The reported betas are the OLS time-series estimates. The MSCI global market index serves as a proxy for the market portfolio. The global Fama-French momentum factor is used to estimate the momentum betas. T-statistics are in brackets, t-statistics are calculated using NW heteroskedasticity consistent standard errors. Nov 1990 - Aug 2013.

\begin{tabular}{|c|c|c|c|c|c|c|}
\hline & 1 & 2 & 3 & 4 & 5 & WML \\
\hline \multicolumn{7}{|c|}{ Panel A: Global momentum portfolios } \\
\hline Average return (\% pa) & 9.35 & 11.43 & 12.76 & 15.50 & 20.48 & 11.13 \\
\hline Standard deviation & 75.04 & 51.93 & 46.72 & 48.23 & 62.46 & 47.84 \\
\hline Skewness & 0.07 & -0.64 & -0.90 & -0.85 & -0.94 & -1.73 \\
\hline Global market beta $(\beta)$ & $\begin{array}{c}1.15 \\
{[11.50]}\end{array}$ & $\begin{array}{c}0.86 \\
{[14.06]}\end{array}$ & $\begin{array}{c}0.78 \\
{[17.05]}\end{array}$ & $\begin{array}{c}0.79 \\
{[18.34]}\end{array}$ & $\begin{array}{c}0.93 \\
{[15.58]}\end{array}$ & $\begin{array}{c}-0.22 \\
{[-2.06]}\end{array}$ \\
\hline Relative downside beta $\left(\beta^{-}-\beta\right)$ & -0.04 & 0.03 & 0.07 & 0.08 & 0.18 & 0.22 \\
\hline Relative upside beta $\left(\beta^{+}-\beta\right)$ & 0.05 & -0.04 & -0.08 & -0.09 & -0.21 & -0.26 \\
\hline \multirow[t]{2}{*}{ Beta asymmetry $\left(\beta^{-}-\beta^{+}\right)$} & -0.10 & 0.07 & 0.15 & 0.17 & 0.39 & 0.49 \\
\hline & {$[-0.32]$} & {$[0.38]$} & {$[1.18]$} & {$[1.82]$} & {$[3.15]$} & {$[2.87]$} \\
\hline \multirow[t]{2}{*}{ Momentum beta } & -0.44 & -0.16 & 0.00 & 0.18 & 0.46 & 0.90 \\
\hline & {$[-3.38]$} & {$[-2.88]$} & {$[0.12]$} & {$[3.65]$} & [4.99] & [17.99] \\
\hline Av. number of stocks & 5545 & 2558 & 2204 & 2145 & 2932 & \\
\hline \multicolumn{7}{|c|}{ Panel B: European momentum portfolios } \\
\hline Average return (\% pa) & 3.60 & 8.42 & 11.23 & 14.71 & 21.18 & 17.58 \\
\hline Standard deviation & 74.19 & 56.98 & 52.79 & 53.09 & 61.65 & 48.30 \\
\hline Skewness & 0.07 & -0.89 & -0.98 & -0.82 & -0.61 & -1.47 \\
\hline Global market beta $(\beta)$ & $\begin{array}{c}1.07 \\
{[9.41]}\end{array}$ & $\begin{array}{c}0.87 \\
{[11.08]}\end{array}$ & $\begin{array}{c}0.80 \\
{[11.86]}\end{array}$ & $\begin{array}{c}0.79 \\
{[12.36]}\end{array}$ & $\begin{array}{c}0.82 \\
{[12.03]}\end{array}$ & $\begin{array}{c}-0.25 \\
{[-2.27]}\end{array}$ \\
\hline Relative downside beta $\left(\beta^{-}-\beta\right)$ & -0.02 & 0.07 & 0.09 & 0.09 & 0.16 & 0.18 \\
\hline Relative upside beta $\left(\beta^{+}-\beta\right)$ & 0.02 & -0.08 & -0.10 & -0.10 & -0.19 & -0.21 \\
\hline \multirow[t]{2}{*}{ Beta asymmetry $\left(\beta^{-}-\beta^{+}\right)$} & -0.04 & 0.15 & 0.19 & 0.19 & 0.34 & 0.39 \\
\hline & {$[-0.13]$} & {$[0.60]$} & [0.99] & [1.18] & {$[2.07]$} & [2.26] \\
\hline \multirow[t]{2}{*}{ Momentum beta } & -0.43 & -0.17 & -0.04 & 0.11 & 0.30 & 0.73 \\
\hline & {$[-3.50]$} & {$[-2.80]$} & {$[-0.76]$} & {$[2.31]$} & {$[4.58]$} & [8.99] \\
\hline Av. number of stocks & 1968 & 884 & 750 & 705 & 966 & \\
\hline
\end{tabular}


Table 3 (Continued). Return and risk characteristics of global momentum portfolios

The table reports return and risk characteristics of 5 global equal-weighted momentum portfolios (panel A) and 5 regional equal-weighted momentum portfolios (panels B-D), and the corresponding winner-minus-loser (WML) momentum portfolios. All portfolios are formed by sorting individual stocks in the corresponding region at time $t$ by their total return in time t-12 to t-2. All returns are converted to USD, annualized and expressed in percent. The reported betas are the OLS time-series estimates. The MSCI global market index serves as a proxy for the market portfolio. The global Fama-French momentum factor is used to estimate the momentum betas. T-statistics are in brackets, t-statistics are calculated using NW heteroskedasticity consistent standard errors. Nov 1990 - Aug 2013.

\begin{tabular}{lcccccc}
\hline & $\mathbf{1}$ & $\mathbf{2}$ & $\mathbf{3}$ & $\mathbf{4}$ & $\mathbf{5}$ & WML \\
\hline & Panel C: Asian-Pacific momentum portfolios & & \\
\hline Average return $(\%$ pa) & 15.83 & 16.63 & 18.28 & 22.27 & 22.38 & 6.55 \\
Standard deviation & 102.75 & 79.77 & 72.61 & 74.89 & 91.98 & 56.46 \\
Skewness & 0.30 & -0.06 & -0.63 & -0.53 & -1.03 & -2.22 \\
Global market beta $(\beta)$ & 1.30 & 1.08 & 1.00 & 1.00 & 1.17 & -0.13 \\
& {$[9.22]$} & {$[10.27]$} & {$[12.48]$} & {$[12.02]$} & {$[11.46]$} & {$[-2.66]$} \\
Relative downside beta $\left(\beta^{-}-\beta\right)$ & -0.15 & -0.02 & 0.07 & 0.08 & 0.14 & 0.29 \\
Relative upside beta $\left(\beta^{+}-\beta\right)$ & 0.17 & 0.02 & -0.09 & -0.09 & -0.17 & -0.34 \\
Beta asymmetry $\left(\beta^{-}-\beta^{+}\right)$ & -0.32 & -0.05 & 0.16 & 0.17 & 0.31 & 0.62 \\
& {$[-0.73]$} & {$[-0.14]$} & {$[0.70]$} & {$[0.80]$} & {$[1.38]$} & {$[3.06]$} \\
Momentum beta & -0.19 & -0.05 & 0.05 & 0.19 & 0.36 & 0.55 \\
& {$[-1.04]$} & {$[-0.39]$} & {$[0.63]$} & {$[1.94]$} & {$[3.26]$} & {$[4.63]$} \\
Av. number of stocks & 885 & 319 & 269 & 270 & 413 & \\
\hline \multicolumn{1}{l}{ Panel D: North-American momentum portfolios } & & \\
\hline Average return $(\%$ pa) & 12.77 & 15.07 & 16.54 & 18.63 & 23.86 & 11.09 \\
Standard deviation & 88.11 & 55.76 & 51.20 & 54.13 & 77.67 & 64.30 \\
Skewness & 0.31 & -0.98 & -1.04 & -0.82 & -0.28 & -1.34 \\
Global market beta $(\beta)$ & 1.23 & 0.88 & 0.80 & 0.82 & 1.03 & -0.20 \\
Relative downside beta $\left(\beta^{-}-\beta\right)$ & {$[10.67]$} & {$[13.67]$} & {$[16.18]$} & {$[16.68]$} & {$[13.31]$} & {$[-3.07]$} \\
Relative upside beta $\left(\beta^{+}-\beta\right)$ & 0.02 & 0.12 & 0.14 & 0.15 & 0.25 & 0.22 \\
Beta asymmetry $\left(\beta^{-}-\beta^{+}\right)$ & -0.03 & -0.15 & -0.17 & -0.18 & -0.29 & -0.26 \\
Momentum beta & 0.05 & 0.27 & 0.31 & 0.33 & 0.54 & 0.49 \\
Av. number of stocks & {$[0.16]$} & {$[1.49]$} & {$[2.37]$} & {$[2.94]$} & {$[2.88]$} & {$[2.08]$} \\
\hline & -0.51 & -0.14 & 0.05 & 0.25 & 0.66 & 1.18 \\
& {$[-2.90]$} & {$[-2.60]$} & {$[0.91]$} & {$[3.73]$} & {$[4.22]$} & {$[18.29]$} \\
& 1990 & 861 & 733 & 753 & 1124 & \\
\hline
\end{tabular}




\section{Table 4. Cross-section regressions for global momentum portfolios}

The table reports the Fama-MacBeth and efficient GMM estimates of risk premiums (in percent per month) obtained for global and regional equal-weighted momentum portfolios (five in each case). All portfolios are formed by sorting individual stocks in the corresponding region at time $\mathrm{t}$ by their total return in time $\mathrm{t}-12$ to $\mathrm{t}-2$. The MSCI global market index serves as a proxy for the market portfolio. T-statistics are in brackets, t-statistics are calculated using NW heteroskedasticity consistent standard errors. J statistics for the over-identifying restrictions is also reported. P-value for J statistics is in parentheses. Nov 1990 - Aug 2013.

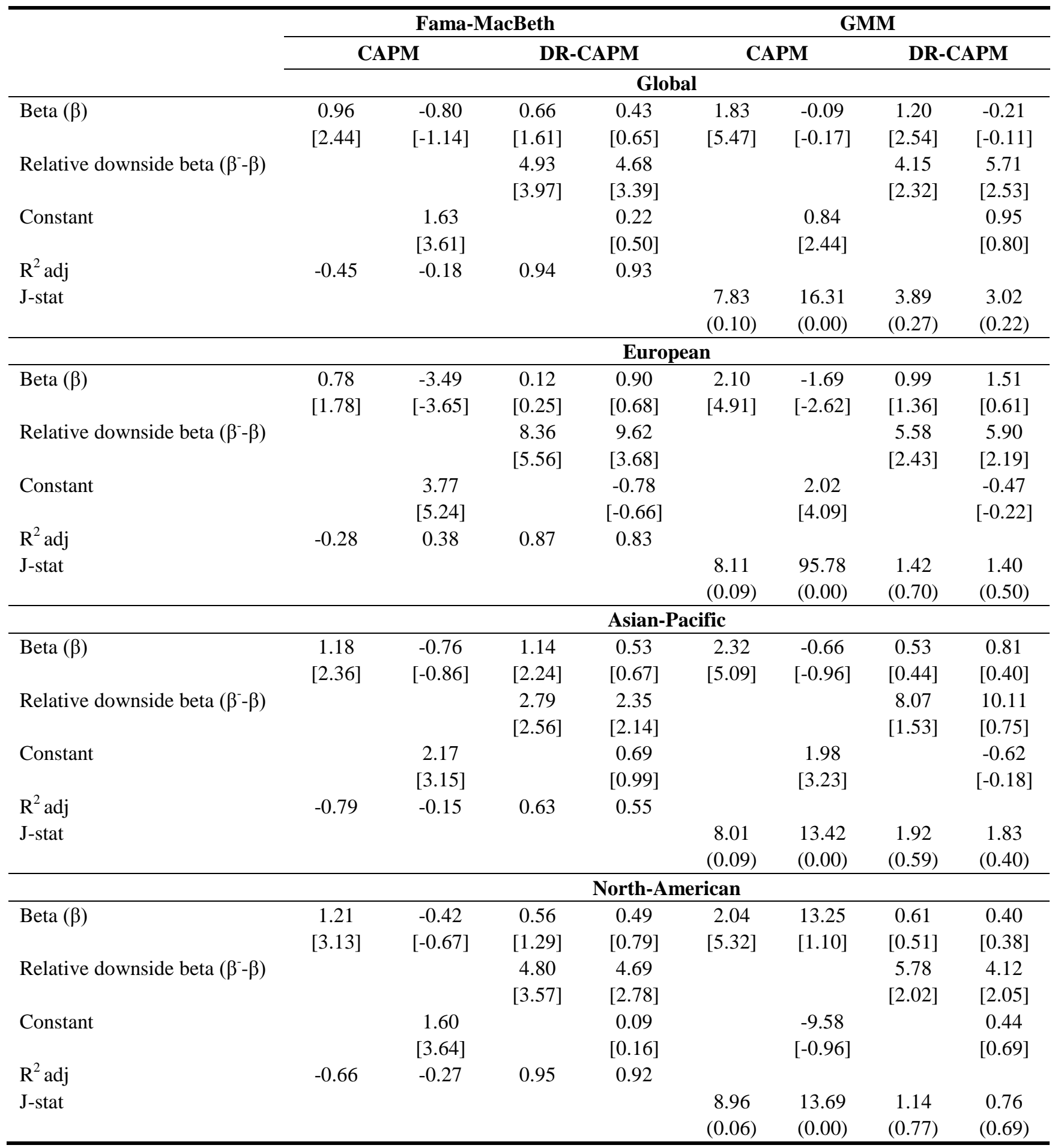




\section{Table 5. Returns and asymmetric betas of 25 global size-momentum portfolios}

The table reports returns and betas of 25 global double-sorted size-momentum portfolios, the winner-minus-loser (WML) momentum portfolios and the small-minus-big (SMB) size portfolios. The returns are annualized and expressed in percent. The betas are the OLS time-series estimates. The global market index serves as a proxy for the market portfolio. T-statistics for the long-short portfolios are reported in brackets. Nov 1990 - Aug 2013.

\begin{tabular}{|c|c|c|c|c|c|c|}
\hline & \multicolumn{6}{|c|}{ Average returns, \% pa } \\
\hline & 1 - low & 2 & 3 & 4 & 5 - high & WML \\
\hline 1 - small & 10.72 & 13.61 & 15.62 & 19.67 & 24.91 & 14.18 \\
\hline 2 & 5.20 & 9.12 & 9.98 & 12.91 & 16.70 & 11.51 \\
\hline 3 & 6.80 & 9.18 & 9.92 & 10.54 & 13.83 & 7.03 \\
\hline 4 & 6.28 & 8.87 & 9.65 & 9.95 & 13.85 & 7.56 \\
\hline 5 - big & 5.96 & 8.44 & 9.86 & 10.35 & 12.63 & 6.67 \\
\hline \multirow[t]{3}{*}{ SMB } & 4.76 & 5.17 & 5.75 & 9.32 & 12.27 & \\
\hline & \multicolumn{6}{|c|}{ Beta asymmetry $\left(\beta^{-}-\beta^{+}\right)$} \\
\hline & 1 - low & 2 & 3 & 4 & 5 - high & WML \\
\hline 1 - small & -0.03 & 0.14 & 0.23 & 0.24 & 0.43 & $0.46[3.17]$ \\
\hline 2 & -0.21 & 0.04 & 0.10 & 0.17 & 0.43 & $0.64[3.53]$ \\
\hline 3 & -0.30 & -0.02 & 0.02 & 0.10 & 0.33 & 0.64 [3.29] \\
\hline 4 & -0.24 & -0.04 & 0.06 & 0.12 & 0.28 & $0.52[2.52]$ \\
\hline 5 - big & -0.26 & 0.00 & 0.05 & 0.08 & 0.25 & 0.51 [2.39] \\
\hline \multirow{4}{*}{ SMB } & 0.23 & 0.14 & 0.18 & 0.16 & 0.18 & \\
\hline & [1.32] & [1.07] & [1.60] & [1.34] & [1.02] & \\
\hline & \multicolumn{6}{|c|}{ Relative downside beta $\left(\beta^{-}-\beta\right)$} \\
\hline & $1-$ low & 2 & 3 & 4 & 5 - high & WML \\
\hline 1 - small & -0.01 & 0.07 & 0.10 & 0.11 & 0.20 & 0.21 \\
\hline 2 & -0.10 & 0.02 & 0.05 & 0.08 & 0.20 & 0.29 \\
\hline 3 & -0.14 & -0.01 & 0.01 & 0.05 & 0.15 & 0.29 \\
\hline 4 & -0.11 & -0.02 & 0.03 & 0.06 & 0.13 & 0.24 \\
\hline 5 - big & -0.12 & 0.00 & 0.02 & 0.04 & 0.11 & 0.23 \\
\hline \multirow[t]{3}{*}{ SMB } & 0.11 & 0.06 & 0.08 & 0.08 & 0.08 & \\
\hline & \multicolumn{6}{|c|}{ Relative upside beta $\left(\beta^{+}-\beta\right)$} \\
\hline & 1 - low & 2 & 3 & 4 & 5 - high & WML \\
\hline 1 - small & 0.02 & -0.08 & -0.12 & -0.13 & -0.23 & -0.25 \\
\hline 2 & 0.11 & -0.02 & -0.06 & -0.09 & -0.23 & -0.35 \\
\hline 3 & 0.16 & 0.01 & -0.01 & -0.06 & -0.18 & -0.34 \\
\hline 4 & 0.13 & 0.02 & -0.03 & -0.07 & -0.15 & -0.28 \\
\hline 5 - big & 0.14 & 0.00 & -0.03 & -0.04 & -0.13 & -0.28 \\
\hline SMB & -0.13 & -0.08 & -0.10 & -0.09 & -0.10 & \\
\hline
\end{tabular}




\section{Table 6. Cross-section regressions for 25 size-momentum portfolios}

The table reports the Fama-MacBeth and the efficient GMM estimates of risk premiums (in percent per month) obtained for 25 global double-sorted size-momentum portfolios. Alternative multi-factor models are estimated in columns (1)-(4). The global market factor, the global momentum factor and the global size factor are used as risk factors. T-statistics are in brackets, t-statistics are calculated using NW heteroskedasticity consistent standard errors. J statistics for the overidentifying restrictions is also reported. P-value for J statistics is in parentheses. Nov 1990 - Aug 2013.

\begin{tabular}{lcccccccc}
\hline & \multicolumn{4}{c}{ Fama-MacBeth } & \multicolumn{4}{c}{ GMM } \\
\cline { 2 - 9 } & $\mathbf{( 1 )}$ & $\mathbf{( 2 )}$ & $\mathbf{3})$ & $\mathbf{( 4 )}$ & $\mathbf{( 1 )}$ & $\mathbf{( 2 )}$ & $\mathbf{( 3 )}$ & $\mathbf{( 4 )}$ \\
\cline { 2 - 9 } Beta $(\beta)$ & $-1,30$ & 0,07 & $-0,75$ & 0,06 & $-3,99$ & 0,81 & $-0,96$ & 0,45 \\
& {$[-2,69]$} & {$[0,14]$} & {$[-2,00]$} & {$[0,14]$} & {$[-7,64]$} & {$[0,69]$} & {$[-2,80]$} & {$[0,32]$} \\
Relative downside beta $\left(\beta^{-}-\beta\right)$ & & 3,61 & & 5,57 & & 5,67 & & 5,27 \\
& & {$[2,64]$} & & {$[5,12]$} & & {$[2,03]$} & & {$[5,19]$} \\
SMB beta & & & 0,48 & 0,55 & & & 1,23 & 0,79 \\
& & & {$[2,84]$} & {$[3,15]$} & & & {$[7,93]$} & {$[4,51]$} \\
Momentum beta & & & 0,62 & 0,62 & & & 0,42 & 0,41 \\
& & & {$[2,13]$} & {$[2,15]$} & & & {$[1,79]$} & {$[1,86]$} \\
Constant & 1,95 & 0,50 & 1,12 & 0,34 & 4,71 & $-0,23$ & 0,94 & $-0,32$ \\
& {$[4,90]$} & {$[1,23]$} & {$[3,51]$} & {$[0,90]$} & {$[8,90]$} & {$[-0,22]$} & {$[3,17]$} & {$[-0,35]$} \\
R2 adj & 0,32 & 0,72 & 0,66 & 0,79 & & & & \\
J-stat & & & & & 22,24 & 29,04 & 22,10 & 23,77 \\
& & & & & $(0,51)$ & $(0,14)$ & $(0,39)$ & $(0,25)$ \\
\hline
\end{tabular}




\section{Table 7. Return and risk characteristics of momentum portfolios of country indices}

The table reports return and risk characteristics of 6 global momentum portfolios, formed by sorting 40 country indices at time $\mathrm{t}$ by their total return in time $\mathrm{t}-12$ to $\mathrm{t}-2$, the winner-minus-loser (WML) portfolio and the US market index. All returns are annualized and expressed in percent. The reported betas are the OLS time-series estimates. The MSCI global market index serves as a proxy for the market portfolio. The global Fama-French momentum factor is used to estimate the momentum betas. T-statistics are in brackets, t-statistics are calculated using $\mathrm{NW}$ heteroskedasticity consistent standard errors. Jan 1984 - Aug 2013.

\begin{tabular}{lcccccccc}
\hline & $\mathbf{1}$ & $\mathbf{2}$ & $\mathbf{3}$ & $\mathbf{4}$ & $\mathbf{5}$ & $\mathbf{6}$ & WML & US ret \\
\hline Return in local currency & 8,05 & 6,20 & 10,16 & 11,47 & 14,01 & 34,23 & 26,18 & 8,99 \\
Exchange rate return & $-1,37$ & 0,38 & 0,67 & 2,42 & 1,99 & $-14,64$ & $-13,26$ & \\
Return in USD & 6,68 & 6,59 & 10,83 & 13,89 & 16,00 & 19,59 & 12,92 & 8,99 \\
Return in excess of US return & $-2,31$ & $-2,40$ & 1,84 & 4,90 & 7,01 & 10,60 & & \\
& {$[-0,58]$} & {$[-0,83]$} & {$[0,58]$} & {$[1,71]$} & {$[2,24]$} & {$[2,71]$} & & \\
Standard deviation & 80,69 & 70,23 & 69,72 & 66,83 & 68,26 & 85,43 & 69,32 & 53,38 \\
Skewness & $-0,31$ & $-0,53$ & $-0,67$ & $-0,71$ & $-0,71$ & $-0,68$ & $-0,05$ & $-0,74$ \\
Global market beta $(\beta)$ & 1,12 & 1,08 & 1,08 & 1,02 & 1,02 & 1,12 & 0,00 & 0,87 \\
& {$[14,68]$} & {$[16,47]$} & {$[22,40]$} & {$[20,29]$} & {$[18,63]$} & {$[13,19]$} & {$[-0,01]$} & {$[23,60]$} \\
Relative downside beta $\left(\beta^{-}-\beta\right)$ & 0,07 & 0,06 & 0,18 & 0,17 & 0,16 & 0,34 & 0,27 & 0,08 \\
Relative upside beta $\left(\beta^{+}-\beta\right)$ & $-0,08$ & $-0,06$ & $-0,20$ & $-0,18$ & $-0,17$ & $-0,37$ & $-0,29$ & $-0,08$ \\
Beta asymmetry $\left(\beta^{-}-\beta^{+}\right)$ & 0,15 & 0,12 & 0,38 & 0,34 & 0,34 & 0,71 & 0,57 & 0,15 \\
& {$[0,76]$} & {$[0,65]$} & {$[3,02]$} & {$[2,68]$} & {$[2,09]$} & {$[3,13]$} & {$[2,12]$} & {$[1,81]$} \\
Global momentum beta & $-0,32$ & $-0,15$ & 0,04 & 0,05 & 0,08 & 0,13 & 0,45 & $-0,02$ \\
& {$[-4,22]$} & {$[-1,95]$} & {$[0,48]$} & {$[0,72]$} & {$[1,26]$} & {$[2,05]$} & {$[5,20]$} & {$[-0,56]$} \\
\hline
\end{tabular}


Table 8. Cross-section regressions for momentum portfolios of country indices

The table reports the Fama-MacBeth and GMM estimates of risk premiums (in percent per month) obtained for the 6 global momentum portfolios, formed by sorting 40 country indices at time t by their total return in time t-12 to t-2. The MSCI global market index serves as a proxy for the market portfolio. T-statistics are in brackets, t-statistics are calculated using NW heteroskedasticity consistent standard errors. J statistics for the over-identifying restrictions is also reported. P-value for J statistics is in parentheses. Jan 1984 - Aug 2013.

\begin{tabular}{|c|c|c|c|c|c|c|c|c|}
\hline \multirow[b]{3}{*}{$\operatorname{Beta}(\beta)$} & \multicolumn{4}{|c|}{ Fama-MacBeth } & \multicolumn{4}{|c|}{ GMM } \\
\hline & \multicolumn{2}{|c|}{ CAPM } & \multicolumn{2}{|c|}{ DR-CAPM } & \multicolumn{2}{|c|}{ CAPM } & \multicolumn{2}{|c|}{ DR-CAPM } \\
\hline & $\begin{array}{c}0.95 \\
{[2.96]}\end{array}$ & $\begin{array}{c}-1.69 \\
{[-0.95]}\end{array}$ & $\begin{array}{c}0.35 \\
{[1.06]}\end{array}$ & $\begin{array}{c}-3.31 \\
{[-1.75]}\end{array}$ & $\begin{array}{c}0.84 \\
{[2.37]}\end{array}$ & $\begin{array}{c}-45.28 \\
{[-0.31]}\end{array}$ & $\begin{array}{c}0.00 \\
{[-0.01]}\end{array}$ & $\begin{array}{c}-2.56 \\
{[-0.87]}\end{array}$ \\
\hline Relative downside beta $\left(\beta^{-}-\beta\right)$ & & & $\begin{array}{c}3.89 \\
{[3.92]}\end{array}$ & $\begin{array}{c}4.08 \\
{[4.02]}\end{array}$ & & & $\begin{array}{c}4.73 \\
{[2.11]}\end{array}$ & $\begin{array}{c}4.37 \\
{[2.10]}\end{array}$ \\
\hline Constant & & $\begin{array}{c}2.84 \\
{[1.55]}\end{array}$ & & $\begin{array}{c}3.90 \\
{[2.06]}\end{array}$ & & $\begin{array}{c}49.33 \\
{[0.31]}\end{array}$ & & $\begin{array}{c}2.80 \\
{[0.94]}\end{array}$ \\
\hline $\mathrm{R}^{2}$ adj & -0.05 & -0.21 & 0.72 & 0.90 & & & & \\
\hline J-stat & & & & & $\begin{array}{l}13.42 \\
(0.02) \\
\end{array}$ & $\begin{array}{r}5.59 \\
(0.23) \\
\end{array}$ & $\begin{array}{c}9.23 \\
(0.06) \\
\end{array}$ & $\begin{array}{r}6.09 \\
(0.11) \\
\end{array}$ \\
\hline
\end{tabular}




\section{Table 9. Returns, risks and risk premiums of currency momentum portfolios}

The table reports return and risk characteristics of 5 currency momentum portfolios, formed by sorting currencies at time $\mathrm{t}$ by their returns in time $\mathrm{t}-12$ to $\mathrm{t}-2$ and held for 1 month, and the 5-1 winner-minus-loser (WML) portfolio (panel A) and the Fama-MacBeth and efficient GMM estimates of risk premiums (panel B). The returns are annualized, whereas the risk premiums are expressed in percent per month. The reported betas are the OLS time-series estimates. The MSCI global market index serves as a proxy for the market portfolio. The global Fama-French momentum factor is used to estimate the equity momentum betas. T-statistics are in brackets, t-statistics are calculated using NW heteroskedasticity consistent standard errors. $\mathbf{J}$ statistics for the over-identifying restrictions is also reported. P-value for $\mathbf{J}$ statistics is in parentheses. Nov 1984 - Aug 2013.

\begin{tabular}{|c|c|c|c|c|c|c|}
\hline & \multicolumn{6}{|c|}{ Panel A: Time-series regressions } \\
\hline & 1 & 2 & 3 & 4 & 5 & WML \\
\hline Exchange rate return (\% pa) & -5.47 & -0.36 & 0.95 & 2.65 & 2,35 & 7,82 \\
\hline Standard deviation & 34.27 & 27.51 & 30.66 & 29.78 & 29.07 & 36.55 \\
\hline Skewness & -0.70 & 0.30 & -0.28 & -0.31 & -0.65 & 0.75 \\
\hline \multirow[t]{2}{*}{ Global market beta $(\beta)$} & 0.24 & 0.18 & 0.22 & 0.20 & 0.21 & -0.03 \\
\hline & {$[5.38]$} & {$[4.32]$} & {$[4.65]$} & {$[4.60]$} & {$[5.12]$} & {$[-0.68]$} \\
\hline Relative downside beta $\left(\beta^{-}-\beta\right)$ & -0.14 & -0.07 & -0.05 & -0.09 & -0.01 & 0.13 \\
\hline Relative upside beta $\left(\beta^{+}-\beta\right)$ & 0.17 & 0.08 & 0.06 & 0.11 & 0.01 & -0.16 \\
\hline \multirow[t]{2}{*}{ Beta asymmetry $\left(\beta^{-}-\beta^{+}\right)$} & -0.31 & -0.15 & -0.12 & -0.19 & -0.01 & 0.30 \\
\hline & {$[-2.22]$} & {$[-1.42]$} & {$[-1.03]$} & {$[-1.78]$} & {$[-0.12]$} & {$[2.43]$} \\
\hline \multirow[t]{5}{*}{ Global equity momentum beta } & -0.10 & -0.06 & 0.02 & 0.03 & 0.09 & 0.19 \\
\hline & {$[-2.51]$} & {$[-1.55]$} & {$[0.61]$} & {$[0.83]$} & {$[2.94]$} & [4.59] \\
\hline & \multicolumn{6}{|c|}{ Panel B: Cross-section regressions } \\
\hline & \multicolumn{3}{|c|}{ Fama-MacBeth } & \multicolumn{3}{|c|}{ GMM } \\
\hline & CAPM & & DR-CAPM & CAPM & & DR-CAPM \\
\hline \multirow[t]{2}{*}{ Beta $(\beta)$} & -1.56 & & -0.21 & -1.91 & & 1.10 \\
\hline & {$[-2.59]$} & & {$[-0.27]$} & {$[-3.24]$} & & {$[0.55]$} \\
\hline \multirow[t]{2}{*}{ Relative downside beta $\left(\beta^{-}-\beta\right)$} & & & 3.97 & & & 4.74 \\
\hline & & & [2.80] & & & {$[2.42]$} \\
\hline $\mathrm{R}^{2}$ adj & 0.15 & & 0.47 & & & \\
\hline \multirow[t]{2}{*}{ J-stat } & & & & 7.91 & & 7.99 \\
\hline & & & & $(0.09)$ & & (0.09) \\
\hline
\end{tabular}


Table 10. Correlation matrix for winner-minus-loser momentum portfolios

The table reports correlation coefficients of returns of 7 global and regional WML portfolios and the global Fama-French momentum factor. T-statistics are in brackets. Nov 1990 - Aug 2013.

\begin{tabular}{|c|c|c|c|c|c|c|c|c|}
\hline & US & Global & European & $\begin{array}{l}\text { Asian- } \\
\text { Pacific }\end{array}$ & $\begin{array}{c}\text { North- } \\
\text { American } \\
\end{array}$ & $\begin{array}{c}\text { Country } \\
\text { indices }\end{array}$ & $\begin{array}{c}\text { Curren } \\
\text { cies }\end{array}$ & $\begin{array}{l}\text { FF mom } \\
\text { factor }\end{array}$ \\
\hline US & 1.00 & & & & & & & \\
\hline Global & $\begin{array}{c}0.80 \\
{[21.68]}\end{array}$ & 1.00 & & & & & & \\
\hline European & $\begin{array}{c}0.56 \\
{[11.06]}\end{array}$ & $\begin{array}{c}0.81 \\
{[22.86]}\end{array}$ & 1.00 & & & & & \\
\hline Asian-Pacific & $\begin{array}{c}0.39 \\
{[7.06]}\end{array}$ & $\begin{array}{c}0.56 \\
{[11.05]}\end{array}$ & $\begin{array}{c}0.29 \\
{[5.01]}\end{array}$ & 1.00 & & & & \\
\hline North-American & $\begin{array}{c}0.89 \\
{[32.34]}\end{array}$ & $\begin{array}{c}0.89 \\
{[32.63]}\end{array}$ & $\begin{array}{c}0.64 \\
{[13.60]}\end{array}$ & $\begin{array}{c}0.44 \\
{[7.97]}\end{array}$ & 1.00 & & & \\
\hline Country indices & $\begin{array}{c}0.24 \\
{[4.01]}\end{array}$ & $\begin{array}{c}0.33 \\
{[5.76]}\end{array}$ & $\begin{array}{c}0.21 \\
{[3.53]}\end{array}$ & $\begin{array}{c}0.34 \\
{[5.93]}\end{array}$ & $\begin{array}{c}0.27 \\
{[4.69]}\end{array}$ & 1.00 & & \\
\hline Currencies & $\begin{array}{c}0.15 \\
{[2.49]}\end{array}$ & $\begin{array}{c}0.21 \\
{[3.55]}\end{array}$ & $\begin{array}{c}0.20 \\
{[3.35]}\end{array}$ & $\begin{array}{c}0.33 \\
{[5.67]}\end{array}$ & $\begin{array}{c}0.17 \\
{[2.92]}\end{array}$ & $\begin{array}{c}0.20 \\
{[3.42]}\end{array}$ & 1.00 & \\
\hline Global FF mom factor & $\begin{array}{c}0.72 \\
{[17.13]}\end{array}$ & $\begin{array}{c}0.92 \\
{[38.91]}\end{array}$ & $\begin{array}{c}0.76 \\
{[19.22]}\end{array}$ & $\begin{array}{c}0.48 \\
{[8.98]}\end{array}$ & $\begin{array}{c}0.88 \\
{[30.17]}\end{array}$ & $\begin{array}{c}0.37 \\
{[6.50]}\end{array}$ & $\begin{array}{c}0.26 \\
{[4.53]}\end{array}$ & 1.00 \\
\hline
\end{tabular}




\section{Table 11. Cross-section regressions for $\mathbf{4 8}$ global and regional momentum portfolios}

The table reports the Fama-MacBeth estimates of risk premiums (in percent per month) obtained for 48 global and regional momentum portfolios. Alternative multi-factor models are estimated in columns (1)-(5). The global market factor and the global momentum factor are used as risk factors. T-statistics are in brackets, t-statistics are calculated using NW heteroskedasticity consistent standard errors. Nov 1990 - Aug 2013.

\begin{tabular}{lccccc}
\hline & $(1)$ & $(2)$ & $(3)$ & $(4)$ & $(5)$ \\
\hline Beta $(\beta)$ & 1.14 & 0.51 & 1.10 & 0.88 & 1.02 \\
& {$[3.03]$} & {$[1.14]$} & {$[2.67]$} & {$[2.12]$} & {$[2.40]$} \\
Relative downside beta $\left(\beta^{-}-\beta\right)$ & & & & 3.94 & 2.79 \\
& & & & {$[3.99]$} & {$[2.06]$} \\
Momentum beta & & & 1.04 & & 0.44 \\
& & & {$[3.39]$} & & {$[1.02]$} \\
Constant & & 0.66 & 0.11 & 0.04 & -0.01 \\
& & {$[3.75]$} & {$[1.08]$} & {$[0.43]$} & {$[-0.06]$} \\
$\mathrm{R}^{2}$ adj & -0.21 & 0.16 & 0.49 & 0.55 & 0.57 \\
\hline
\end{tabular}




\section{Table 12. Cross-section regressions for reversal portfolios}

The table reports the Fama-MacBeth estimates of risk premiums (in percent per month) obtained for 10 value-weighted US short-term reversal portfolios and 10 value-weighted US long-term reversal portfolios. The short-term reversal portfolios are formed by sorting stocks in month $t$ by their return in month $t-1$. The long-term reversal portfolios are formed by sorting stocks in month t by their return in the preceding 5-year period. The US market index serves as a proxy for the market portfolio. T-statistics are in brackets, t-statistics are calculated using NW heteroskedasticity consistent standard errors. The sample period is Jan 1927 - July 2013 for the short-term reversal portfolios and Jan 1931 - July 2013 for the long-term reversal portfolios.

\begin{tabular}{|c|c|c|c|c|}
\hline & \multicolumn{2}{|c|}{ CAPM } & \multicolumn{2}{|c|}{ DR-CAPM } \\
\hline & \multicolumn{4}{|c|}{ Short-term reversal } \\
\hline \multirow[t]{2}{*}{$\operatorname{Beta}(\beta)$} & 0.65 & 0.88 & 0.71 & 1.02 \\
\hline & {$[3.70]$} & {$[2.37]$} & {$[4.04]$} & [2.59] \\
\hline \multirow[t]{2}{*}{ Relative downside beta $\left(\beta^{-}-\beta\right)$} & & & 1.62 & 1.67 \\
\hline & & & {$[2.35]$} & {$[2.35]$} \\
\hline \multirow[t]{2}{*}{ Constant } & & -0.26 & & -0.34 \\
\hline & & {$[-0.69]$} & & {$[-0.87]$} \\
\hline \multirow[t]{2}{*}{$\mathrm{R}^{2}$} & 0.18 & 0.19 & 0.35 & 0.38 \\
\hline & \multicolumn{4}{|c|}{ Long-term reversal } \\
\hline \multirow[t]{2}{*}{$\operatorname{Beta}(\beta)$} & 0.74 & 1.28 & 0.64 & 0.49 \\
\hline & {$[2.05]$} & {$[2.52]$} & [1.48] & {$[1.10]$} \\
\hline \multirow[t]{2}{*}{ Relative downside beta $\left(\beta^{-}-\beta\right)$} & & & 0.93 & 1.04 \\
\hline & & & {$[1.62]$} & [1.73] \\
\hline \multirow[t]{2}{*}{ Constant } & & -0.61 & & 0.15 \\
\hline & & {$[-1.23]$} & & {$[0.36]$} \\
\hline $\mathrm{R}^{2}$ & 0.61 & 0.74 & 0.93 & 0.94 \\
\hline
\end{tabular}




\section{Online appendix}

\section{Return and risk characteristics of US momentum portfolios in sub-periods}

The table reports return and risk characteristics of 10 value-weighted US momentum portfolios, formed by sorting NYSE, AMEX, and NASDAQ stocks at time $\mathrm{t}$ by their total return in time $\mathrm{t}-12$ to $\mathrm{t}-2$, and the corresponding winnerminus-loser (WML) portfolios. The returns are annualized and expressed in percent. The reported betas are the OLS time-series estimates. The US market index serves as a proxy for the market portfolio. Jan 1927 - July 2013.

\begin{tabular}{|c|c|c|c|c|c|c|c|c|c|c|c|}
\hline & Low & 2 & 3 & 4 & 5 & 6 & 7 & 8 & 9 & High & WML \\
\hline & \multicolumn{11}{|c|}{$1927-1969$} \\
\hline Average return $(\%$ pa $)$ & 6,00 & 8,63 & 6,74 & 9,27 & 10,81 & 11,21 & 12,59 & 13,77 & 15,42 & 19,27 & 13,27 \\
\hline US market beta & 1,60 & 1,43 & 1,26 & 1,18 & 1,10 & 1,08 & 1,02 & 0,95 & 0,97 & 0,95 & $-0,66$ \\
\hline Relative downside beta & $-0,34$ & $-0,23$ & $-0,13$ & $-0,20$ & $-0,12$ & $-0,07$ & $-0,02$ & 0,03 & 0,11 & 0,21 & 0,55 \\
\hline Relative upside beta & 0,28 & 0,19 & 0,10 & 0,16 & 0,10 & 0,06 & 0,01 & $-0,03$ & $-0,09$ & $-0,18$ & $-0,45$ \\
\hline \multirow[t]{2}{*}{ Beta asymmetry } & $-0,62$ & $-0,41$ & $-0,23$ & $-0,36$ & $-0,22$ & $-0,14$ & $-0,03$ & 0,06 & 0,20 & 0,39 & 1,00 \\
\hline & \multicolumn{11}{|c|}{$1970-2013$} \\
\hline Average return $(\%$ pa) & 2,01 & 8,66 & 10,85 & 11,47 & 10,23 & 11,22 & 11,90 & 13,34 & 13,60 & 17,26 & 15,25 \\
\hline US market beta & 1,45 & 1,19 & 1,03 & 0,96 & 0,92 & 0,93 & 0,89 & 0,91 & 0,97 & 1,16 & $-0,29$ \\
\hline Relative downside beta & $-0,13$ & $-0,12$ & $-0,14$ & $-0,06$ & $-0,03$ & 0,02 & 0,00 & $-0,01$ & 0,07 & 0,06 & 0,19 \\
\hline Relative upside beta & 0,12 & 0,12 & 0,13 & 0,06 & 0,03 & $-0,02$ & 0,00 & 0,01 & $-0,06$ & $-0,05$ & $-0,18$ \\
\hline \multirow[t]{2}{*}{ Beta asymmetry } & $-0,25$ & $-0,24$ & $-0,27$ & $-0,12$ & $-0,06$ & 0,04 & 0,00 & $-0,02$ & 0,13 & 0,11 & 0,37 \\
\hline & \multicolumn{11}{|c|}{$2000-2013$} \\
\hline Average return (\% pa) & 2,86 & 6,38 & 6,83 & 9,23 & 8,52 & 6,42 & 7,67 & 7,52 & 6,27 & 7,19 & 4,34 \\
\hline US market beta & 1,95 & 1,41 & 1,14 & 0,98 & 0,88 & 0,84 & 0,78 & 0,78 & 0,86 & 1,08 & $-0,86$ \\
\hline Relative downside beta & $-0,45$ & $-0,16$ & $-0,20$ & $-0,10$ & $-0,15$ & 0,05 & $-0,03$ & 0,04 & 0,08 & 0,07 & 0,53 \\
\hline Relative upside beta & 0,55 & 0,20 & 0,25 & 0,12 & 0,18 & $-0,06$ & 0,04 & $-0,05$ & $-0,10$ & $-0,09$ & $-0,64$ \\
\hline Beta asymmetry & $-1,00$ & $-0,36$ & $-0,45$ & $-0,21$ & $-0,33$ & 0,11 & $-0,07$ & 0,09 & 0,18 & 0,17 & 1,17 \\
\hline
\end{tabular}

